Article

\title{
Comparative Analysis of Dental Pulp and Periodontal Stem Cells: Differences in Morphology, Functionality, Osteogenic Differentiation and Proteome
}

\author{
Anastasia V. Kotova ${ }^{1,2}$, Arseniy A. Lobov ${ }^{1} \mathbb{D}$, Julia A. Dombrovskaya ${ }^{2}$, Valentina Y. Sannikova ${ }^{1}$ (D), \\ Nadezhda A. Ryumina ${ }^{3}$, Polina Klausen ${ }^{1}$, Alexey L. Shavarda ${ }^{4}$, Anna B. Malashicheva ${ }^{1} \mathbb{D}$ \\ and Natella I. Enukashvily 1,2,*(D)
}

check for updates

Citation: Kotova, A.V.; Lobov, A.A.; Dombrovskaya, J.A.; Sannikova, V.Y.; Ryumina, N.A.; Klausen, P.; Shavarda, A.L.; Malashicheva, A.B.; Enukashvily, N.I. Comparative Analysis of Dental Pulp and

Periodontal Stem Cells: Differences in Morphology, Functionality, Osteogenic Differentiation and Proteome. Biomedicines 2021, 9, 1606. https://doi.org/10.3390/

biomedicines 9111606

Academic Editor: David T. Harris

Received: 17 October 2021

Accepted: 30 October 2021

Published: 3 November 2021

Publisher's Note: MDPI stays neutral with regard to jurisdictional claims in published maps and institutional affiliations.

Copyright: (c) 2021 by the authors. Licensee MDPI, Basel, Switzerland. This article is an open access article distributed under the terms and conditions of the Creative Commons Attribution (CC BY) license (https:/ / creativecommons.org/licenses/by/ $4.0 /)$.
1 Institute of Cytology of the Russian Academy of Sciences, 194064 St. Petersburg, Russia; anastkotova@gmail.com (A.V.K.); arseniylobov@gmail.com (A.A.L.); valent.sannikova@gmail.com (V.Y.S.); polina.klauzen@gmail.com (P.K.); amalashicheva@gmail.com (A.B.M.)

2 Cell Technologies Laboratory, General Dentistry Department, North-Western State Medical University, 191015 St. Petersburg, Russia; Yuliya.Dombrovskaya@szgmu.ru

3 Cell Technologies Center Pokrovsky, LLC, 199106 St. Petersburg, Russia; nadiy007@yandex.ru

4 Research Resource Center Molecular and Cell Technologies, Saint-Petersburg State University, 199034 St. Petersburg, Russia; shavarda@binran.ru

* Correspondence: n.enukashvily@incras.ru

\begin{abstract}
Dental stem cells are heterogeneous in their properties. Despite their common origin from neural crest stem cells, they have different functional capacities and biological functions due to niche influence. In this study, we assessed the differences between dental pulp stem cells (DPSC) and periodontal ligament stem cells (PDLSC) in their pluripotency and neuroepithelial markers transcription, morphological and functional features, osteoblast/odontoblast differentiation and proteomic profile during osteogenic differentiation. The data were collected in paired observations: two cell cultures, DPSC and PDLSC, were obtained from each donor. Both populations had the mesenchymal stem cells surface marker set exposed on their membranes but differed in Nestin (a marker of neuroectodermal origin) expression, morphology, and proliferation rate. OCT4 mRNA was revealed in DPSC and PDLSC, while OCT4 protein was present in the nuclei of DPSC only. However, transcription of OCT4 mRNA was 1000-10,000-fold lower in dental stem cells than in blastocysts. DPSC proliferated at a slower rate and have a shape closer to polygonal but they responded better to osteogenic stimuli as compared to PDLSC. RUNX2 mRNA was detected by qPCR in both types of dental stem cells but RUNX2 protein was detected by LC-MS/MS shotgun proteomics only in PDLSC suggesting the posttranscriptional regulation. DSPP and DMP1, marker genes of odontoblastic type of osteogenic differentiation, were transcribed in DPSC but not in PDLSC samples. Our results prove that DPSC and PDLSC are different in their biology and therapeutic potential: DPSC are a good candidate for osteogenic or odontogenic bone-replacement cell-seeded medicines, while fast proliferating PDLSC are a prospective candidate for other cell products.
\end{abstract}

Keywords: dental stem cells; dental pulp stem cells; periodontal ligament stem cells; osteogenic differentiation; odontoblastic differentiation; pluripotency; somatic OCT4; SSEA-4; proteomics; mass-spectrometry

\section{Introduction}

A unique group of stem cells, isolated from dental and periodontal tissues, exhibit self-renewal, and multilineage differentiation capacity. These cells exhibit properties similar to bone marrow stem/stromal cells, the 'gold standard' of mesenchymal stromal cells (MSC) [1,2]. A specific feature that distinguishes tooth stem cells from MSC is their neuroectodermal origin. These cells originating from migrating neural crest cells represent a multipotent cell population derived from the lateral ridges of the neural plate during 
craniofacial development [3]. During embryogenesis, the progenitor cells migrated from the neural crest are involved in the formation of tooth buds. The neural crest is also referred as the fourth germ layer, because many organs and tissues are formed from its cells. Cells migrating from the neural crest can't be called "stem" in the strict sense of the word, since the properties related to stemness are more limited in these cells than in 'true' stem cells. However, they are multipotent. Dental stem cells are heterogeneous in their properties as neural crest 'stem' cells. Tooth pulp contains various types of cells such as endothelial cells, neurons, fibroblasts, osteoblasts, osteoclasts, odontoblasts as well as cells that are referred as postnatal dental pulp stem cells (DPSCs). Also, four more types of dental stem cell-like populations were identified and characterized: stem cells from human exfoliated deciduous teeth (SHED), periodontal ligament stem cells (PDLSC), stem cells from the apical papilla (SCAP), and population of dental follicle-derived progenitor cells (DFPCs) [1] It has been hypothesized that different populations of oral cavity-derived stem cells have different physiological features. The differences in cell biology arise due to the specific neighborhood surrounding different populations of dental stem cells.

Colonies grown from single cells have different proliferative and differentiation potentials [1,4-6]. In addition, some cells express a number of pluripotent markers, such as OCT4, SSEA-4, Nanog, and some others, which in embryonic cells are involved in maintaining their proliferative activity and undifferentiated state [7-9]. There is a possibility that a subpopulation of the progenitor cells of the neural crest, expressing these markers, persists after migration and formation of tissues in adult tissues and organs, preserving their stem potential. However, there is no direct evidence of this hypothesis yet.

Dental stem cells are capable of multilineage differentiation. They have three MSC 'classical' differentiation capacities (osteogenic, adipogenic, and chondrogenic) along with the cranial neural crest progenitor cells ones: they give rise to neurons, myoblasts, and odontoblasts $[1,4,10-13]$. It has turned out that dental stem cells are able to differentiate rather into odontoblasts than into osteoblasts under the influence of osteogenic factors [11,14-16]. The ability for odontoblastic differentiation is one of the most important features of pulp stem cells. A striking feature of pulp stem cells is their ability to form a complex resembling a tooth when transplanted into immunosuppressed mice cells with hydroxyapatite/tricalcium phosphate $[17,18]$. Transplanted cells form a vascularized pulp-like tissue surrounded by a layer of odontoblast-like cells expressing dentin sialophosphoprotein (DSPP). The tissue produces dentin-containing dentinal tubules, similar to natural dentin. If DPSC are seeded onto dentin, some of them turn into odontoblast-like cells with a polarized cell body $[16,19]$. However, the proteomic analysis of dental stem cells before and after osteogenic differentiation is far from being complete.

Among all dental stem cells, DPSC and PDLSC are obtained most easily: teeth are often extracted during dental treatment or maxillofacial surgery and the periodontal ligament is usually attached to an extracted tooth. Thus, DPSC and PDLSC can be obtained from medicinal waste tissues. The populations can be easily separated at the first step of cells isolation. DPSC and PDLSC differ in their biology and hence, probably, in their therapeutic potential. However, to prove that, studies on paired samples (i.e., different tissues from the same donors) are necessary.

The aim of this work was to assess the differences between DPSC and PDLC in their pluripotency and neuroepithelial markers transcription, morphological and functional features, osteoblast/odontoblast differentiation markers, and proteomic profile during osteogenic differentiation. The data were collected for paired samples: two cell cultures, DPSC and PDLSC, were obtained from each donor.

According to our data, both populations had the MSC surface marker set exposed on their membranes. At the same time, NES RNA, a marker of neuroectodermal origin, was revealed by qPCR in DPSC but not in PDLSC. OCT4 protein was present in the nuclei of DPSC and PDLSC, while OCT4 mRNA was revealed in DPSC and PDLSC total RNA. However, transcription of OCT4 mRNA was 1000-10,000-fold lower in dental stem cells than in blastocysts. The low level of OCT4 transcription combined with the data about 
the low intensity of the nuclear staining led to a suggestion that it does not function as a pluripotency maintaining transcription factor but plays a different role in dental stem cells. Nevertheless, the presence of pluripotency markers even in low quantity suggests that the safety and the absence of tumorigenicity should be thoroughly evaluated for these cells. Our data of paired observations suggest that DPSC and PDLSC are different in their rate of proliferation, pluripotency markers, morphology and osteogenic potential. The data confirm the influence of the niche on the cells of the same origin. DPSC proliferate at a slower rate and have a shape closer to polygonal but they respond better to osteogenic stimuli as compared to PDLSC. RUNX2 mRNA was detected by qPCR in the both types of dental stem cells but RUNX2 protein was detected by LC-MS/MS shotgun proteomics only in PDLSC suggesting the posttranscriptional regulation. Surprisingly, proteome analysis revealed that RUNX2 was interacting with a lesser number of proteins in osteogenically differentiating PDLSC than in undifferentiated cells while in undifferentiated PDLSC, RUNX2 might be suppressed by histone deacetylases HDAC1 and HDAC2. DSPP, a marker gene of odontoblastic type of osteogenic differentiation, was transcribed in DPSC but not in PDLSC samples. Our results prove that DPSC and PDLSC are different in their biology and therapeutic potential: DPSC are a good candidate for osteogenic or bone-replacement cell-seeded medicines while fast proliferating PDLSC are a prospective candidate for other cell products.

\section{Materials and Methods}

\subsection{Bioethics}

All procedures performed in the study involving human beings complied with the ethical standards of the institutional and/or national research ethics committee and the 1964 Helsinki Declaration and its subsequent changes or comparable ethical standards (Declaration of Helsinki: Ethical Principles for Medical Research Involving Human Subjects, including amendments made by the 64th Meeting of World Medical Association in Fortaleza, Brazil, October 2013). An informed written consent was obtained from each of the participants enrolled in the study (or his/her parents for underage).

Children and blastocysts: The ethical committee of Mechnikov North-Western State Medical University approved isolation and expansion in vitro primary PDLSC and DPSC cultures (ethical vote No 12, date of issue 12 December 2019). The local ethical committee of Ava-Peter-Scandinavia assisted reproduction clinics approved the usage of blastocysts in the study (ethical vote \#2/23-10-2018, date of issue 23/10/2018)

\subsection{Cells}

Primary cultures of dental stem cells were obtained from donors (median age of the donors $-22.1 \pm 4.2$ years) without systemic diseases and pulp diseases, tooth decay, pulpitis, periodontal disease, denticles.

We obtained successfully 12 pairs (i.e., paired samples from the same tooth of the same donor) of DPSC and PDLSC: twelve DPSC cultures from adult teeth $(n=12)$, and twelve PDLSC cultures $(n=12)$.

Human third molars with residual periodontal ligament were collected from patients during surgical extraction under local anesthesia with articaine (1:200,000). The extraction was performed for medical reasons-dystopia or retention. Teeth with periodontal tissues were transported in isotonic $\mathrm{NaCl}$ solution containing $100 \mathrm{U} / \mathrm{mL}$ penicillin and $100 \mu \mathrm{g} / \mathrm{mL}$ streptomycin (ThermoFisher Sci, Waltham, MA, USA) at room temperature. The periodontal ligament tissue of the permanent molar root was scraped off with a sterile scalpel and digested in a phosphatx10-buffered saline (PBS) (Life Technologies, Carlsbad, CA, USA) containing $1 \mathrm{mg} / \mathrm{mL}$ collagenase type I (ThermoFisher Sci, Waltham, MA, USA), and $1 \mathrm{mg} / \mathrm{mL}$ collagenase type IV (ThermoFisher Sci, Waltham, MA, USA) for 40 min at $37^{\circ} \mathrm{C}$ in a shaker incubator. The tooth with closed root canals and an inseparable part of ligaments was also placed in a similar solution and incubated for $1 \mathrm{hr}$. Then, a tooth was removed and the collagenase solution was centrifuged at $400 \times g$ for $7 \mathrm{~min}$. The 
pellet was resuspended in a Dulbecco's modified Eagle, low glucose medium (DMEM LG GlutaMAX, ThermoFisher Sci, Waltham, MA, USA) supplemented with 10\% FBS (fetal bovine serum; HyClone, Logan, UT, USA), $100 \mathrm{U} / \mathrm{mL}$ penicillin, and $100 \mu \mathrm{g} / \mathrm{mL}$ streptomycin (Life Technologies, USA). The cells were seeded into a flask (TPP, Trasadingen, Switzerland) and were further grown at $37^{\circ} \mathrm{C}$ in a humidified $5 \% \mathrm{CO}_{2} / 7 \% \mathrm{O}_{2}$ atmosphere. The tooth was transferred after treatment with collagenases into $70 \%$ ethanol for $3 \mathrm{~min}$ to kill periodontal ligament cells. To obtain DPSC, the internal cavity of the tooth was filled with the collagenase solution through the apical foramen; the tooth was incubated at $37^{\circ} \mathrm{C}$, and then the dissociated pulp was removed through a root channel by pumping saline with a syringe. If the roots were closed or too narrow, the pulp chamber was opened in a sterile environment. The pulp was gently isolated by a syringe needle. The excised pulp tissue was chopped into 1-2 $\mathrm{mm}^{2}$ pieces, incubated in collagenases solution, washed and seeded into the cell culture medium as described above for periodontal ligamentum.

Frozen unhatched blastocysts or morulas (5-6 days after in vitro fertilization) stored no less than 5 years were taken for the study if parents decided to donate them for research purposes and declared their decision in written informed consent. The blastocysts were thawed according to the protocol developed by Kitazato Company, incubated in Quinn's Advantage Blastocyst medium (Cooper Surgical, Trumbull, CT, USA) supplemented with $2 \%$ bovine serum albumin (BSA) for $1 \mathrm{~h}$ and were further used either for RNA isolation or immunocytochemistry studies as a control sample enriched in pluripotency markers. RNA was isolated using the ExtractRNA kit (Evrogen, Moscow, Russia) and was reversetranscribed with MMLV RT kit (Evrogen, Moscow, Russia). For immunochytochemistry staining, blastocysts were put on extra-adhesive X-tra Surgipath slides (Leica, Wetzlar, Germany) in a drop of Quinn's Advantage Blastocyst medium (Cooper Surgical, Trumbull, CT, USA) and in 5 min the remained medium was replaced with $4 \%$ formaldehyde in PBS. After 45 min of fixation at room temperature, the cells were permeabilized with $0.05 \%$ Triton X-100 in PBS.

\subsection{Proliferation Rate Assay}

PDLSC or DPSC were plated at $1.00 \times 10^{4}$ cells/well. Cells were detached and counted using a cell-counting chamber (Minimed, Bryansk, Russia) and Luna Cell counter (Logos Biosystems, Anyang-si, South Korea) on days 2, 3, 5 and 7 after seeding.

The average number of days between passages was also calculated at each splitting. At each passage, cells were re-plated at the initial density, and subculturing was performed until passage 15.

\subsection{Immunophenotyping}

Cell immunophenotyping was performed using a flow cytometer Navios (Beckman Coulter, Brea, CA, USA) equipped with 2 lasers (488 nm and $638 \mathrm{~nm}), 8$ fluorescence detectors and the original standard set of light filters (Blue Laser: 525/40, 575/30, 620/30, 695/30, 755LP; Red Laser: 660/20, 725/20, 755 LP). The staining and detection were performed according to the standard protocols recommended by the manufacturer.

After the epithelial-mesenchymal transition, neural crest stem cells usually start to express a set of surface markers typical for mesenchymal stem cells (MSC). Therefore, the following monoclonal antibody panels were used to identify positive and negative surface markers typical for MSC [20]: CD44-FITC/CD73-PE/CD90-PC5/CD105-PC7 and CD34FITC/CD117-PE/CD14-PC5/CD45-PC7 (Beckman Coulter, Brea, CA, USA). Cells were subjected to flow cytometry on the 2nd passage. Autofluorescence level was evaluated using an unstained control sample. The level of non-specific binding of antibodies was determined using isotypic controls (mouse immunoglobulins conjugated to FITC, PE, PC5, PC7). Gating of fluorescence events was carried out using the viability parameter. The viability was estimated by forward and side scattering along with 7-aminoactinomycin $\mathrm{D}$ staining. In each sample, at least 15,000 "targeted events" (events determined as viable cells) were analyzed. 


\subsection{The Osteogenic Differentiation of Dental Stem Cells}

MSC at passage 3 were seeded at a density of $10^{4}$ per well into 6 well plates as described above. When cells reached $90-100 \%$ confluency, the medium was changed to $\mathrm{MSCgo}^{\mathrm{TM}}$ Osteogenic (BioInd, Sartorius Group, Göttingen, Germany) for 28 days in order to induce osteogenic differentiation. When the influence of different cell culture conditions was accessed, cells were grown either in Low glucose DMEM or $\alpha$-MEM supplemented with 10\% FBS, 2 mM L-glutamine, 1\% penicillin/streptomycin (HyClone, Logan, UT, USA), $50 \mathrm{mg} / \mathrm{mL}$ ascorbic acid (Sigma Aldrich, St. Louis, MO, USA), $0.1 \mathrm{mM}$ dexamethasone (Sigma Aldrich, St. Louis, MO, USA) and $10 \mathrm{mM} \beta$-glycerophosphate (Sigma Aldrich, St. Louis, MO, USA) either in normoxia $\left(20 \% \mathrm{O}_{2}\right)$ or in $7 \% \mathrm{O}_{2}$. Cells were harvested for RNA isolation on days 5, 10. For calcifications staining, cells were fixed with $10 \%$ paraformaldehyde (30 min at room temperature) on day 28 and stained with Alizarin Red (Sigma Aldrich, St. Louis, MO, USA) according to a standard protocol.

\subsection{Real-Time Quantitative PCR (RT-qPCR) Analysis}

Total RNA from dental stem cells was isolated using GenElute Mammalian Total RNA Miniprep Kit (Sigma Aldrich, St. Louis, MO, USA). The RNA concentration was measured with a spectrophotometer (NanoQuant Infinite F200 PRO, TECAN). Total RNA $(1 \mu \mathrm{g})$ was reverse-transcribed with MMLV RT kit (Evrogen, Moscow, Russia). Real-time PCR was performed with 50 ng cDNA and SYBRGreen PCR Mastermix (Evrogen, Moscow, Russia) using CFX96 Real-Time System (Bio-Rad, Hercules, CA, USA). The thermocycling conditions were as follows: $95^{\circ} \mathrm{C}$ for $5 \mathrm{~min}$, followed by 45 cycles at $95^{\circ} \mathrm{C}$ for $15 \mathrm{~s}, 60^{\circ} \mathrm{C}$ for $30 \mathrm{~s}$ and $70{ }^{\circ} \mathrm{C}$ for $30 \mathrm{~s}$ (a 3-steps protocol is recommended by the PCR master-mix manufacturer). A final heating step of $65^{\circ} \mathrm{C}$ to $95{ }^{\circ} \mathrm{C}$ was performed to obtain melting curves of the final PCR products. mRNA expression levels were calculated by the $2^{-\Delta \Delta \mathrm{Ct}}$ method with the levels of gene transcription normalized to the housekeeping genes GAPDH encoding glyceraldehyde 3-phosphate dehydrogenase (GAPDH) and ACTB encoding $\beta$ actin. Human blastocysts were used as a positive control to evaluate the quantity of OCT4 mRNA in dental cell cultures. The list of primers used for targeted genes amplification is shown in Table 1.

Table 1. List of primers used for quantification of targeted genes transcription.

\begin{tabular}{|c|c|c|}
\hline Encoded Protein & Primer Sequence & \\
\hline Alkaline Phosphatase (ALP) forward [21] & 5'-TCAGAAGCTCAACACCAACG-3' & \multirow{2}{*}{ A marker of osteogenic differentiation } \\
\hline Alkaline Phosphatase (ALP) reverse [21] & 5'-GTCAGGGACCTGGGCATT-3' & \\
\hline $\begin{array}{l}\text { Runt-related transcription factor } 2 \\
\text { (Cbfa-1/RUNX2) forward [22] }\end{array}$ & 5'-CCGCCTCAGTGATTTAGGGC-3 & \multirow{2}{*}{$\begin{array}{c}\text { An early marker of } \\
\text { osteogenic differentiation }\end{array}$} \\
\hline $\begin{array}{l}\text { Runt-related transcription factor } 2 \\
\text { (Cbfa-1/RUNX2) reverse [22] }\end{array}$ & 5'-GGGTCTGTAATCTGACTCTGTCC-3 & \\
\hline $\begin{array}{l}\text { Dentin Sialophosphoprotein (DSPP) } \\
\text { forward (own design) }\end{array}$ & 5'-TCAGAGACACATGCTGTTGGG & \multirow{2}{*}{$\begin{array}{l}\text { A dentin protein, a marker of } \\
\text { odontoblastic differentiation }\end{array}$} \\
\hline $\begin{array}{l}\text { Dentin Sialophosphoprotein (DSPP) } \\
\text { reverse (own design) }\end{array}$ & 5'-CTTTACCTTCGTTGCCTTTCCC-3 & \\
\hline $\begin{array}{l}\text { Dentin Matrix Acidic Phosphoprotein } 1 \\
\text { (DMP1) Forward (own design) }\end{array}$ & 5'-TCTTTGTGAACTACGGAGGGT-3 & \multirow{2}{*}{$\begin{array}{c}\text { A marker of } \\
\text { odontoblastic differentiation }\end{array}$} \\
\hline $\begin{array}{l}\text { Dentin Matrix Acidic Phosphoprotein } 1 \\
\text { (DMP1) Reverse (own design) }\end{array}$ & 5'-CCTGGTTACTGGGAGAGCAC-3 & \\
\hline Nestin forward [23] & 5'-GCGTTGGAACAGAGGTTGGA-3' & \multirow{2}{*}{$\begin{array}{l}\text { A marker of stem cells of neural } \\
\text { crest origin }\end{array}$} \\
\hline Nestin reverse [23] & 5'-TGGGAGCAAAGATCCAAGAC-3' & \\
\hline OCT4 forward [24] & 5'-ACATCAAAGCTCTGCAGAAAGA-3' & \multirow{2}{*}{ A pluripotency marker } \\
\hline OCT4 reverse [24] & 5'-AATACСТTCССAAATAGAACCC-3' & \\
\hline
\end{tabular}


Table 1. Cont.

\begin{tabular}{cc}
\hline Encoded Protein & Primer Sequence \\
\hline $\begin{array}{c}\text { glyceraldehyde 3-phosphate } \\
\text { dehydrogenase (GAPDH) forward } \\
\text { (own design) }\end{array}$ & $5^{\prime}$-AGGTCGGAGTCAACGGATTT-3' \\
\hline $\begin{array}{c}\text { glyceraldehyde 3-phosphate } \\
\text { dehydrogenase (GAPDH) reverse } \\
\text { (own design) }\end{array}$ & $5^{\prime}$-TTCCCGTTCTCAGCCTTGAC-3' \\
\hline $\begin{array}{c}\text { (-actin (ACTB) forward [21] } \\
\beta \text {-actin (ACTB) reverse [21] }\end{array}$ & $5^{\prime}$-ATTGCCGACAGGATGCAGA-3' \\
\hline $5^{\prime}$-GAGTACTTGCGCTCAGGAGGA-3' \\
\hline
\end{tabular}

\subsection{Immunofluorescence Staining}

Cells grown on coverslips (SPL Life Sciences, Pocheon-si, Republic of Korea) were washed twice in PBS, fixed with $4 \%$ paraformaldehyde and permeabilized with $0.1 \%$ Triton X-100. After blocking overnight with 5\% BSA, the cells were incubated with a primary antibody against OCT4/3 (1:200, STEMCELL Technologies, Vancouver, British Columbia, Canada) for $2 \mathrm{~h}$ at $37^{\circ} \mathrm{C}$ in a humidified $5 \% \mathrm{CO}_{2}$ incubator. After washing three times in PBS, an Alexa Fluor 488- conjugated secondary antibody (1:200) was added for $1 \mathrm{~h}$. After washing three times in $1 \times$ PBS buffer, phycoerythrin-conjugated antibody against SSEA-4 (1:100) (STEMCELL Technologies, Vancouver, British Columbia, Canada) was added for $1 \mathrm{~h}$. Cells were mounted in Slowfade ${ }^{\circledR}$ antifade medium with DAPI (ThermoFisher Sci, Waltham, MA, USA). Human blastocysts enriched in OCT4 and SSEA-4 proteins were used as a positive control for staining.

\subsection{Microscopy}

Image acquisition was performed using an Olympus FV3000 confocal microscope (Nikon, Tokyo, Japan). To detect DAPI, FITC and Cy3, the 405, 488, and $561 \mathrm{~nm}$ diode lasers were used for excitation, respectively. The cells were optically sectioned in the $z$-axis with a $0.8 \mu \mathrm{M}$ interval. Brightness-contrast-intensity correction was applied using the built-in software. Image acquisition for proliferation assay and calcifications estimation was performed with an AxioVert.A1 microscope (Carl Zeiss, Oberkochen, Germany).

\subsection{Statistical Analysis}

All experiments were repeated at least three times. Each experiment was carried out in triplicates. Values are means \pm standard deviation. A comparison of mean values between groups was evaluated by a two-tailed Student's $t$-test using the GraphPad Prism software. $p$ values $<0.05$ and less were considered as significant.

\subsection{Proteomics Analysis}

DPSCs and PDLSCs at passage 3 were seeded into $90 \mathrm{~mm}$ Petri dishes (Eppendorf AG, Hamburg, Germany) and cultured in standard conditions with DMEM (ThermoFisher Sci, Waltham, MA, USA) supplemented with 10\% fetal bovine serum (HyClone, Logan, UT, USA), $37{ }^{\circ} \mathrm{C}, 5 \% \mathrm{CO}_{2}$. When cells reached $90-100 \%$ confluency, the medium was changed to osteogenic medium prepared ex tempore (Low glucose DMEM supplemented with 10\% FBS, 2 mM L-glutamine, 1\% penicillin/streptomycin (HyClone, Logan, UT, USA), $50 \mathrm{mg} / \mathrm{mL}$ ascorbic acid (Sigma Aldrich, USA), $0.1 \mathrm{mM}$ dexamethasone (Sigma Aldrich, USA) and $10 \mathrm{mM} \beta$-glycerophosphate (Sigma Aldrich, St. Louis, MO, USA).

Control and differentiated (10th day after induction of osteogenic differentiation) cells were lysed by RIPA lysis buffer (ThermoFisher Sci, Waltham, MA, USA) with SIGMAFAST protease inhibitor cocktail (Sigma Aldrich, St. Louis, MO, USA) then the lysates were collected to microcentrifuge tubes, frozen, sonicated and centrifuged (15 min, 16,000 $\mathrm{g}$, $\left.4{ }^{\circ} \mathrm{C}\right)$. 


\subsubsection{Shotgun Proteomics}

Proteins were cleaned by acetone precipitation (EM grade; EMS, Hatfield, PA, USA) and were resuspended in $8 \mathrm{M}$ Urea/50 mM ammonium bicarbonate (Sigma Aldrich, St. Louis, MO, USA). Then the protein concentration was measured by Qubit 4.0 fluorometer (Thermo Fisher Sci, Waltham, MA, USA) with QuDye Protein Quantification Kit (Lumiprobe, Moscow, Russia). Protein quantification was verified by protein electrophoresis.

The samples $\left(20 \mu \mathrm{g}\right.$ ) were incubated for $1 \mathrm{~h}$ at $37^{\circ} \mathrm{C}$ with $5 \mathrm{mM}$ DTT (Sigma Aldrich, St. Louis, MO, USA) with subsequent incubation in $15 \mathrm{mM}$ iodoacetamide for $30 \mathrm{~min}$ in the dark at RT (Sigma Aldrich, St. Louis, MO, USA). Next, the samples were diluted with seven volumes of $50 \mathrm{mM}$ ammonium bicarbonate and incubated for $16 \mathrm{~h}$ at $37^{\circ} \mathrm{C}$ with $400 \mathrm{ng}$ of Trypsin Gold (ratio 1:50; Promega, Madison, WI, USA). A half of each sample was then evaporated in Labconco Centrivap Centrifugal Concentrator (Labconco, Kansas City, $\mathrm{MO}, \mathrm{USA}$ ) and the quality of digestion was verified by protein electrophoresis. The other half of the sample was mixed with formic acid (Sigma Aldrich, St. Louis, MO, USA) to $1 \%$ final concentration, evaporated in Labconco Centrivap Centrifugal Concentrator and desalted with C18 ZipTip (MilliporeSigma, Burlington, MA, USA) according to manufacturer recommendations. Desalted peptides were evaporated and dissolved in $20 \mu \mathrm{L}$ of water $/ 0.1 \%$ formic acid for further LC-MS/MS analysis.

Approximate $500 \mathrm{ng}$ of peptides were used for shotgun proteomics analysis by UHPLC-MS/MS with ion mobility in TimsToF Pro mass spectrometer (Bruker Daltonics, Bremen, Germany) with nanoElute UHPLC system (Bruker Daltonics, Bremen, Germany). UHPLC was performed in two-column separation mode with Acclaim ${ }^{\text {TM }}$ PepMap ${ }^{\text {TM }} 5 \mathrm{~mm}$ Trap Cartridge (Thermo Fisher Scientific, Waltham, MA, USA) and Bruker Fifteen separation column (C18 ReproSil AQ, $150 \mathrm{~mm} \times 0.75 \mathrm{~mm}, 1.9 \mu \mathrm{m}, 120 \mathrm{~A}$; Bruker Daltonics, Bremen, Germany) in gradient mode with $400 \mathrm{~nL} / \mathrm{min}$ flow rate. Phase A was water $/ 0.1 \%$ formic acid, phase $\mathrm{B}$ was acetonitrile $/ 0.1 \%$ formic acid. The gradient was from $2 \%$ to $35 \%$ phase B for $30 \mathrm{~min}$, then to $95 \%$ of phase B for 1 min with subsequent wash with $95 \%$ phase $B$ for $5 \mathrm{~min}$. The column was equilibrated with 4 column volumes before each sample. CaptiveSpray ion source was used for electrospray ionization with $1600 \mathrm{~V}$ of capillary voltage, $31 / \mathrm{min} \mathrm{N} 2$ flow, and $180^{\circ} \mathrm{C}$ source temperature. The mass spectrometry acquisition was performed in automatic DDA PASEF mode with $0.5 \mathrm{~s}$ cycle in positive polarity with the fragmentation of ions with at least two charges in $\mathrm{m} / \mathrm{z}$ range from 100 to 1700 and ion mobility range from 0.85 to $1.301 / \mathrm{K} 0$.

Protein identification was performed in Peaks Xpro software (a license granted to St. Petersburg State University; Bioinformatics Solutions Inc., Waterloo, ON, Canada) using human protein SwissProt database (https: / / www.uniprot.org/; accessed on 17 October 2021; organism: Human [9606]; uploaded on 2 March 2021; 20,394 sequences) and protein contaminants database CRAP (https://www.thegpm.org/crap/; version of 4 March 2019; accessed on 17 October 2021). The search parameters were: parent mass error tolerance $15 \mathrm{ppm}$ and fragment mass error tolerance $0.05 \mathrm{ppm}$, protein and peptide FDR less than $1 \%$, two possible missed cleavage sites, proteins with at least two unique peptides were included for further analysis. Cysteine carbamidomethylation was set as fixed modification. Methionine oxidation, acetylation of protein $\mathrm{N}$-term, asparagine, and glutamine deamidation were set as variable modifications.

The mass spectrometry proteomics data and protein identification results have been deposited to the ProteomeXchange Consortium via the PRIDE [25] partner repository with the dataset identifier PXD027719 and 10.6019/PXD027719.

Label-free quantification by peak area under the curve was used for further analysis in R (version 3.6.1; R Core Team, 2019). First of all, we performed qualitative analysis-all proteins presented in both biological replicates were identified and the biological groups were compared by Venn diagram with "VennDiagram" package (https:/ / cran.r-project.org/ web/packages/VennDiagram/VennDiagram.pdf, accessed on 17 October 2021) [26]. Then the proteins with NA in more than $85 \%$ of samples were removed and imputation of missed values by k-nearest neighbors was performed by the "impute" package [27]. Then log- 
transformation and quantile normalization with further analysis of differential expression by "limma" package were performed [28]. Finally, we performed ordination of samples by principal component analysis and classification of samples by sparse partial least squares discriminant analysis in the package "MixOmics" [29]. "ggplot2" and "EnhancedVolcano" packages were used for visualization [30,31]. Reproducible code for data analysis is available from https: / github.com/ArseniyLobov/Proteomic-comparison-of-DPSCs-andPDLSCs.git (accessed on 17 October 2021).

Functional annotation was performed by the Database for Annotation, Visualization and Integrated Discovery (DAVID) v6.8 (https:// david.ncifcrf.gov/, accessed on 26 June 2021; [32]). For the prediction of possible clusters of counteracting proteins, we performed string protein interaction analysis [33].

\subsubsection{Gel-Based Proteomics}

Two-Dimensional Difference Gel Electrophoresis (2D DIGE) was performed as described earlier [34]. Prior to electrophoresis $35 \mu \mathrm{g}$ of each sample were conjugated with 400 pM of Cy2, Cy3 or Cy5 fluorophores for 2D electrophoresis according to manufacturer recommendations (Lumiprobe, Moscow, Russia). Then, three samples were mixed and loaded to ready IPG-strip for two-dimensional electrophoresis ( $\mathrm{pH} 3-10,7 \mathrm{~cm}$, BioRad Laboratories, USA) by passive rehydration overnight at RT in the dark. Separation in the first direction was carried out in a Protean IEF Cell (Bio-Rad, Hercules, CA, USA) using the method recommended by the IPG-strip manufacturer: 10,000 Vh, end voltage $4000 \mathrm{~V}$, rapid ramp, $20^{\circ} \mathrm{C}$. After isoelectric focusing, IPG-strips were sequentially incubated in two equilibration buffers (6 M urea, 2\% SDS, 20\% glycerin, $0.375 \mathrm{M}$ Tris, $\mathrm{pH} 8.8$ ) for $10 \mathrm{~min}$ in each of them. The first buffer was supplemented with $2 \%$ dithiothreitol and the second one-with 2.5\% iodoacetamide. The second direction of 2D-electrophoresis was performed in a MiniProtean TetraCell (Bio-Rad, Hercules, CA, USA) in 12\% PAAG in Tris/glycine/SDS buffer. Multiplex visualization of different $\mathrm{Cy}$ fluorophores was performed in Typhoon FLA 9500 laser scanner (GE Healthcare, Chicago, IL, USA). Each sample was analyzed at least in two technical replicates with different Cy fluorophores.

Raw electropherograms are deposited to the ProteomeXchange Consortium together with shotgun proteomics data with the dataset identifier PXD027719 and 10.6019/PXD027719.

For protein identification, 2D-electrophoresis was repeated similar to 2D DIGE, but with one sample per gel and without $\mathrm{Cy}$ fluorophores. For spot excision, gels were stained by Coomassie Brilliant Blue G-250 (Sigma Aldrich, St. Louis, MO, USA).

After excision, proteins were digested by the standard protocol of "in-gel" digestion described earlier [34]. Fragments of PAAG were cut to pieces and washed three times with $50 \mathrm{mM}$ ammonium bicarbonate/50\% acetonitrile. Then the gels were dehydrated by acetonitrile, dried up and rehydrated with bovine trypsin solution $(20 \mathrm{ng} / \mathrm{uL}$ in $50 \mathrm{mM}$ ammonium bicarbonate; Sigma Aldrich, St. Louis, MO, USA). Trypsinolysis was performed at $37{ }^{\circ} \mathrm{C}$ overnight. Then tryptic peptides were extracted by $50 \%$ acetonitrile $/ 0.1 \%$ formic acid, evaporated in Labconco Centrivap Centrifugal Concentrator, and desalted with C18 ZipTip. Protein identification was performed in at least two technical replicates for each protein spot.

Mass spectrometry identification of tryptic peptides from protein spots was similar to shotgun proteomics except for chromatographic separation method: UHPLC was performed with Bruker Ten separation column (C18 ReproSil AQ, $100 \mathrm{~mm} \times 0.75 \mathrm{~mm}, 1.9 \mu \mathrm{m}$, 120 A; Bruker Daltonics, Bremen, Germany) with similar, but shorter gradient (17.1 min). Protein identification was performed in Peaks Xpro with the same parameters as for the shotgun proteomics.

\section{Results}

3.1. Morphological Evaluation, Proliferation Rate, Expression of Cell Surface Markers

Morphology of cells growing in vitro is an important parameter. Mesenchymal stromal cells and dental stem cells usually have spindle-like fibroblasts morphology at the 
beginning of expansion in vitro. Spindle-like cells are often organized in groups with the same orientation of 'spindles' (i.e., cells' long axis). Cells from some cultures, especially from those, that proliferate slowly, often have polygonal shape and grow more irregularly. In our study, in 5-6 days after cells isolation, adherent fibroblast-like spindle colonies were observed in all primary cultures. After two passages, PDLSCs as well as DPSCs cultures consisted of fibroblasts-like cells only. PDLSC usually have spindle-like morphology (Figure 1b), while DPSC cultures' morphology was more variable-in most of the primary cultures, cells had polygonal shape though some had spindle-like morphology (Figure 1a,c). DPSC and PDLSC also differed in their proliferation rate (Figure 1d). The interval before the first passaging was significantly shorter for PDLSC than for DPSC (Figure 1d): $12.0 \pm 2.8$ vs. $20.0 \pm 1,4(p=0,0001)$. After continuing cell expansion, DPSC had a lower proliferation rate (passaging frequency 5-7 days) than PDLSC had (passaging frequency-2-3 days). Pulp stem cells were also the first to stop growing in the culture after passage 10, while PDLSC could be passaged 15 or more times (Figure 1d).

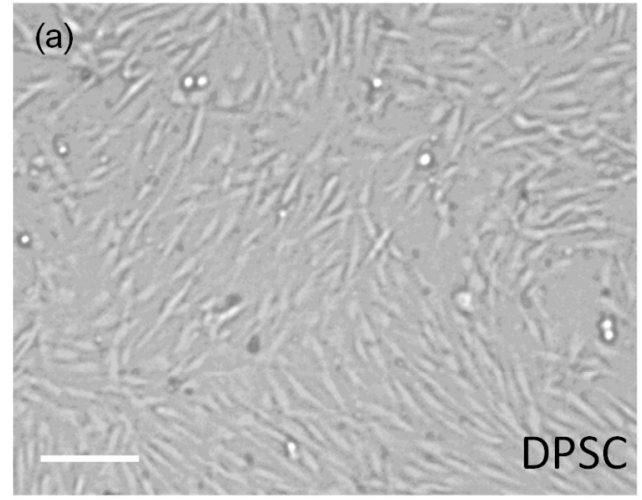

(c)

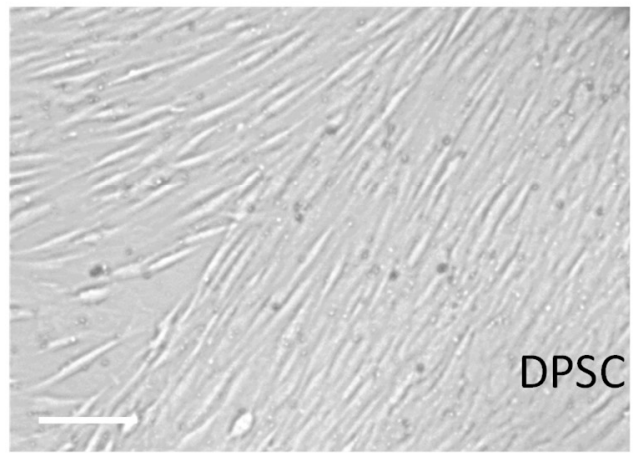

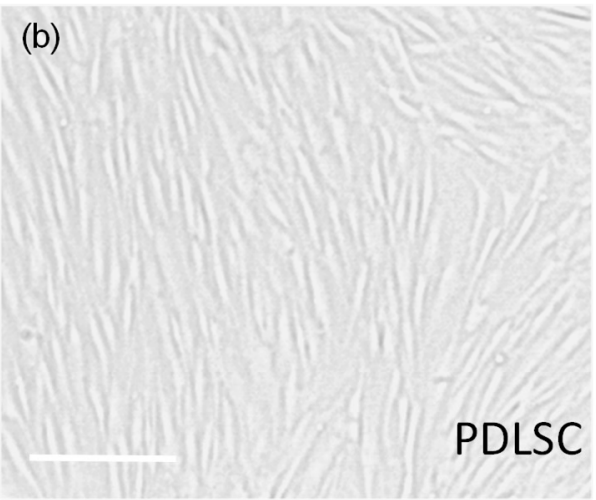

(d)

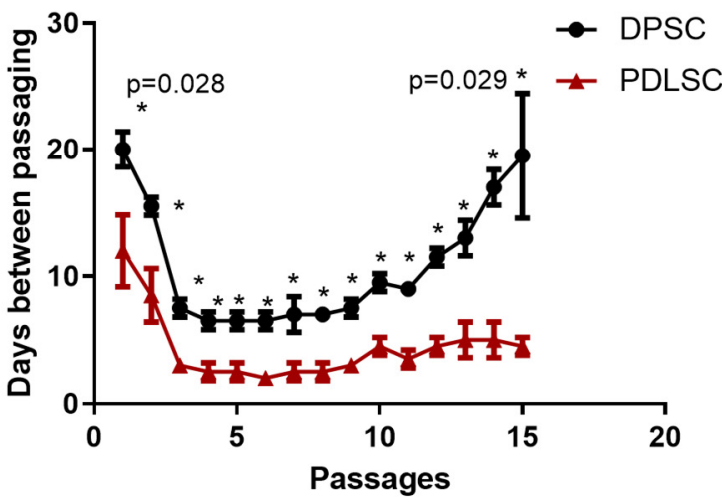

Figure 1. Dental pulp stem cells (DPSC) and periodontal ligament stem cells (PDLSC): morphology (a-c), proliferation rate and maximal period of growing in vitro (d). (a) Irregularly shaped DPSC, (b) Spindle-like PDLSC, (c) Spindle-like DPSC. (d) Time between passaging of DPSC and PDLSC cultures. X-axis—number of passages, $Y$-axis—days between passages, * - significant $(p<0.05)$ difference between PDLSC and DPSC at the same passage (the exact $p$-value is given for the first and last passages). Scale- $50 \mathrm{mkm}$.

Dental stem cells had mesenchymal morphology and immunophenotype (a set of surface markers). The set of MSC cell surface markers [20] on DPSC and PDLSC membranes was analyzed by flow cytometry. Most of the primary stem cells cultures met the MSC criteria established by International Stem Cell Therapy Society. More than $95 \%$ of cells were positive for positive MSC markers (CD44, CD90, CD105, CD73) and less than 5\% were positive for negative MSC markers (Table 2). However, in both PDSC and PDLSC, a subpopulation of CD117(c-kit)-positive cells was detected. The marker was detected only in cultures at the early passages and disappeared at passage 5 or later. 
Table 2. The number of cells expressing positive and negative surface markers of MSC in cell cultures (passage 2) obtained from the dental pulp of permanent teeth (DPSC) and the periodontal ligament (PDLSC).

\begin{tabular}{cccc}
\hline \multirow{2}{*}{ Surface Antigens } & & DPSC & PDLSC \\
\hline \multirow{3}{*}{ Positive markers of MSC } & CD44 & $98.5 \pm 0.65$ & $97.4 \pm 0.5$ \\
\cline { 2 - 4 } & CD73 & $97.9 \pm 0.61$ & $98.8 \pm 0.9$ \\
\cline { 2 - 4 } & CD90 & $99.0 \pm 0.69$ & $97.4 \pm 0.71$ \\
\cline { 2 - 4 } Negative markers of MSC & CD105 & $98.5 \pm 0.72$ & $97.2 \pm 0.62$ \\
\cline { 2 - 4 } & CD14 & $1.2 \pm 0.05$ & $2.1 \pm 0.81$ \\
\cline { 2 - 4 } & CD34 & $0.84 \pm 0.31$ & $0.42 \pm 0.21$ \\
\cline { 2 - 4 } & CD45 & $2.1 \pm 0.92$ & $1.45 \pm 0.56$ \\
\hline
\end{tabular}

Thus, both DPSC and PDLSC have mesenchymal stromal cells morphology and the set of surface markers. However, both populations are enriched in CD117 at the beginning of the expansion in vitro. Despite these similarities, PDLSC were the most rapidly proliferating, while DPSC proliferated slowly and quickly ceased to grow in the culture.

\subsection{Transcription of Nestin (NES) Gene}

Dental stem cells are very close to MSC in their morphology and surface markers. However, they express ectodermal markers such as a neuroepithelial stem cell protein, Nestin (NES), originally described as a specific glial marker $[4,5,35,36]$. Now it is assumed that NES is related to essential stem cell functions, including self-renewal/proliferation, differentiation, and migration [37]. Therefore, we measured the level of Nestin (NES) gene transcription in pairs DPSC/PDLSC from the same donors to access the difference between these populations. The level of NES transcription was higher in DPSCs than in PDLSC in all pairs where the transcription was revealed (Figure 2). However, the difference in transcription varied between donors (Figure $2 b$ ). Cells from PDLSC/DPSC pairs from two donors did not transcribe NES probably due to clonal selection during cell expansion in vitro.

(a)

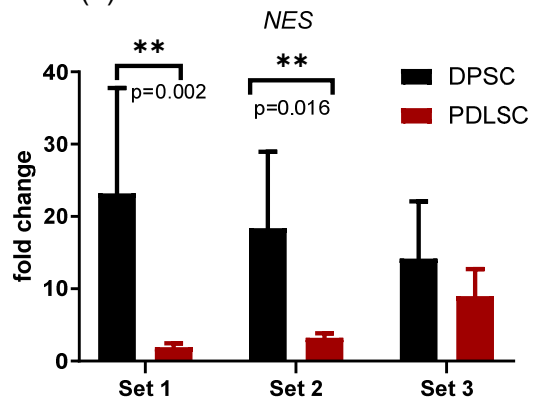

(b)

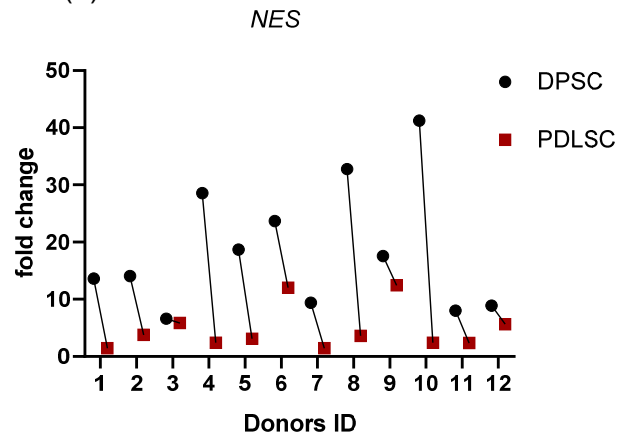

Figure 2. Nestin gene (NES) transcription in PDLSC and DPSC quantified by qPCR: comparison between samples obtained from the same donor. (a) Average values (mean and standard deviation) obtained in three different experiments (set 1 , set 2 , set $3 ; n=4$ in each set); (b) the values for each donor (donors ID are plotted on the $X$-axis) are shown to demonstrate the variability between donors. $Y$-axis—fold change. The reference gene-GAPdH. ${ }^{* *}-p<0.01$ (the exact $p$-values are also shown). 


\subsection{Pluripotency Markers in PDLSC and DPSC}

Dental stem cells can express pluripotency markers such as OCT4 and SSEA-4 [7-9]. However, it is not known, whether there is any difference between dental stem cells of different origin. Moreover, the OCT4 gene (OCT4) transcription was not quantified against pluripotent stem cells such as blastocyst's inner mass cells that transcribe OCT4 at a very high level.

The presence of OCT4 RNA in RNA samples was accessed by qPCR with corresponding primers (Table 1). OCT4 mRNA was detected in cDNA obtained both from PDLSC and DPSC though the level of transcription was very low: $0.0011 \pm 0.0004$ and $0.0005 \pm 0.0001$ (Figure 3a) of the level in a blastocyst (its transcription was set as 1). Transcription in dental stem cells varied from 0.0003 to 0.002 of the level in blastocysts. The transcription level of the OCT4 gene among the DPSCs/PDLSCs paired (taken from the same donor) samples varied both within and between the pairs. In the pair obtained from donor 1, the level of OCT4 expression in the PDLSCs was 5 times higher than in the DPSCs. One of the pairs showed the same level of OCT4 expression within the DPSCs/PDLSCs pair but differed from the others by a low level of expression (Figure 3a). Thus, the OCT4 gene was transcribed both in DPSC and PDLSC though at a very low and variable level.

(a)

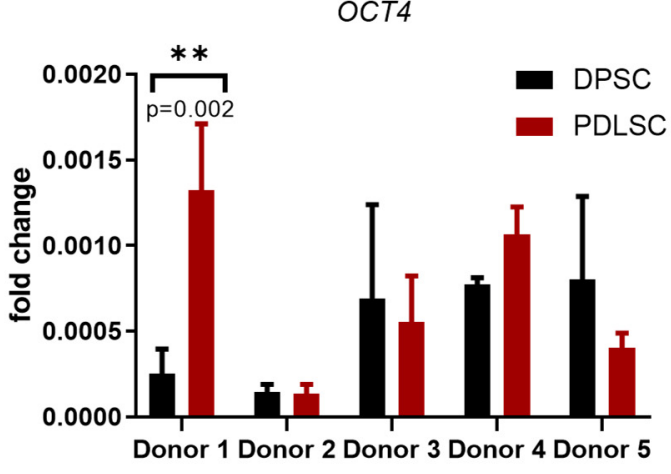

(b)
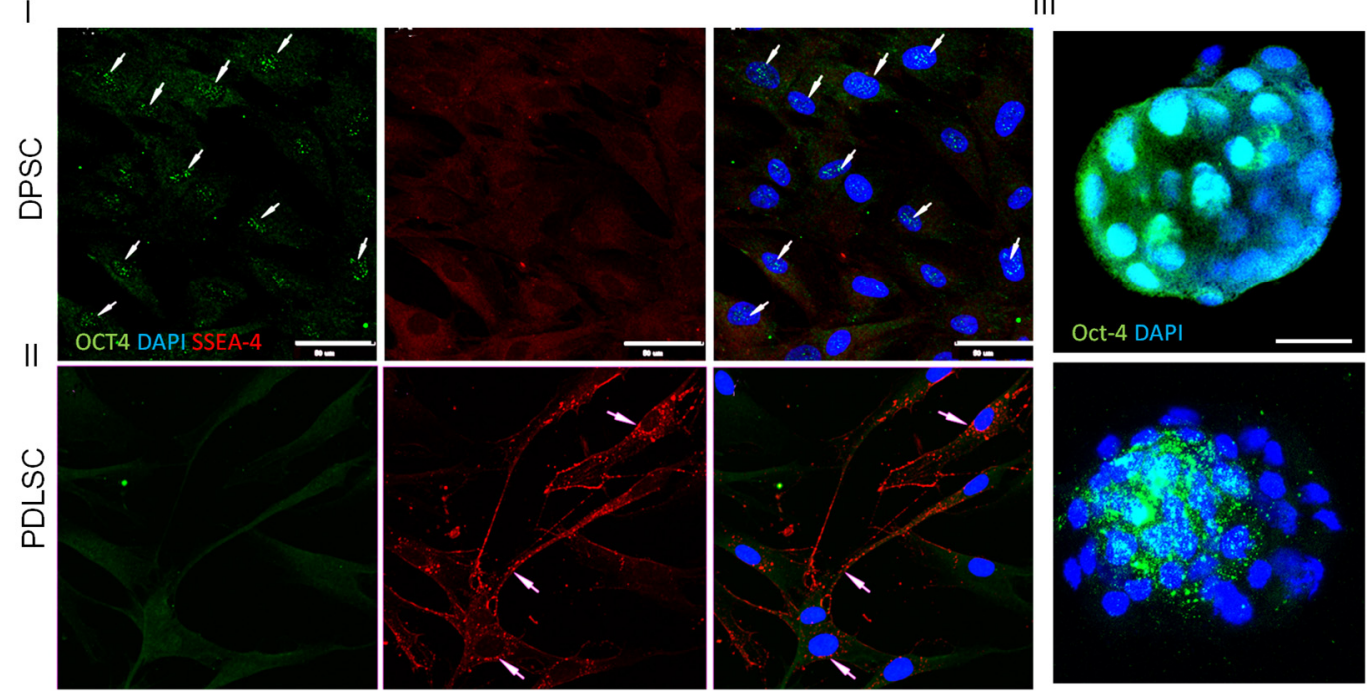

Figure 3. OCT4 and SSEA-4 in DPSC and PDLSC. (a) Quantification of OCT4 mRNA by qPCR. References: GAPdH, $\beta$-actin, positive control-blastocyst's total RNA. ${ }^{* *}-p<0.01$ (the exact $p$-value is also shown); (b) Immunofluorescent staining of DPSC (panel I), PDLSC (panel II) with the ABs against OCT4 (green) and SSEA-4 (red). Panel III-a morula (upper image) and a blastocyst (bottom image) stained with the AB against OCT4. According to the previously published data, these two stages are positively stained for OCT4 [38] and were therefore taken as a positive control in our study. Nuclei are counterstained with DAPI (blue). White arrows-positive staining with the AB. Scale bars (50 mkm) are shown in the images. 
OCT4 mRNA was revealed by qPCR (Figure 3a). Earlier the gene transcription was demonstrated in some somatic cells $[39,40]$, but sometimes, the protein was revealed only in the cytoplasm [41,42]. This cytoplasmic protein is not involved in pluripotency maintenance because to establish its function, the protein must act as a transcription factor. Therefore, the OCT4 protein localization was probed by immunostaining with an antibody against it. We also performed staining with an antibody against SSEA-4-another pluripotency marker [43] that had been suggested as a pluripotency marker for living cell flow cytometry because of its exposition on the cell membrane in pluripotent stem cells [44-46]. Most of the DPSC (approximately 80\%) were positive for OCT4 protein that was localized exclusively in the nucleus interior but not in the cytoplasm (Figure 3b). The cells were not stained with the AB against SSEA-4 (Figure 3b, panel I, red). PDLSC samples were negatively stained with the antiOCT4 AB (Figure 3b, panel II, green). However, SSEA-4 positive signals were revealed in the cytoplasm of approximately 5\% of PDLSC. Many signals from the AB delineated the cell membrane (Figure 3b, panel II, red). Both in PDLSC and DPSC, we did not found cells with OCT4 + /SSEA-4+ immunophenotype, which is a feature of adult Very Small Embryonic-Like Stem cells (VSEL) [47] or embryonic stem cells $[45,48]$.

Thus, DPSC and PDLSC do not express pluripotency markers at the same level as pluripotent embryonic stem cells. However, in DPSC, OCT4 is present in nuclei though in small quantity.

\subsection{Osteogenic Differentiation}

The pluripotency of dental stem cells is still controversial. However, their osteogenic capacity is well-proven $[1,10,49,50]$. The ability of dental stem cells to respond to osteogenic stimuli either with osteogenic, or cementogenic, or odontogenic differentiation has been demonstrated [49,51]. DMP1 and DSPP, classic odontoblastic markers, are expressed in odontoblasts, dentinal tubules. Their presence is necessary during dentine matrix mineralization [12,35,52]. The osteogenic potential of dental stem cells is probably one of the most important characteristics for their clinical application. Therefore, we studied the rate of osteogenic differentiation, performed a qPCR analysis of osteogenic and odontogenic markers' transcription in DPSC and PDLSC after osteogenic induction (Figure 4a-d) and compared their proteomes by shotgun proteomics and two-dimensional electrophoresis (see below, Section 3.5). Both populations responded to osteogenic stimuli. On day 20 of incubation in an osteogenic medium, osteogenic differentiation was confirmed by heavy Alizarin red staining (Figure $4 b$, panels I, II) though one of the PDLSC cell cultures was responding very slowly to the induction (Figure $4 \mathrm{~b}$, panel III). DPSC were the fastest responding to osteogenic stimuli-the first calcifications appeared on day $6.25 \pm 0.45$ while in PDLSC cultures, they were first observed on day $14.10 \pm 1.52$ (Figure 4a). The delay in response to osteogenic stimuli was confirmed for PDLSC by qPCR (Figure 4c,d). In $72 \mathrm{~h}$ after the beginning of osteogenic induction, the mRNA level of RUNX2 (an early marker of osteogenic/odontogenic differentiation) as well as DSPP and DMP1 (odontogenic differentiation markers) were lower in PDLSC as compared to DPSC. The level of transcription depended on culturing conditions: $\mathrm{O}_{2}$ concentration (hypoxia/normoxia) and cell culture medium (DMEM with glucose $1 \mathrm{~g} / \mathrm{L}$ vs. $\alpha \mathrm{MEM}$ ). The highest level of transcription was observed in cells cultured in low glucose DMEM in hypoxia conditions (Figure 4c). During the first 15 days of differentiation, the transcription level of $A L P, R U N X 2, D S P P, D M P 1$ was reliably higher in DPSC cells than in PDLSC (Figure 4d). Odontogenic markers and RUNX2 transcription was increasing faster in DPSC. On day 15, the level of DMP1 mRNA in DPSC increased 15,807.90 \pm 2901.24-fold $(X \pm \mathrm{m})$ vs. $49.01 \pm 10.1$-fold in PDLSC; the level of DSPP increased 93,037.99 \pm 7314.69-fold in PDSC while in PDLSC, it was downregulated to $0.25 \pm 0.04$ (Figure $4 \mathrm{~d}$ ). 
(a)

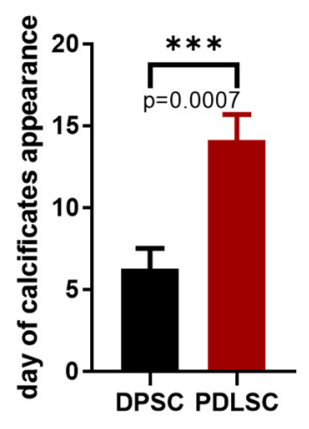

(c)
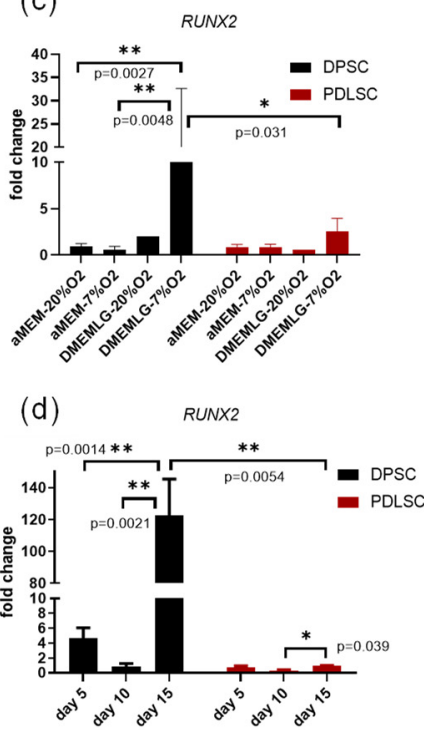

DPSC PDLSC

(b) Control Induced Induced Control

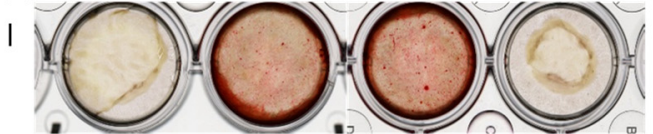

Control Induced Control Induced
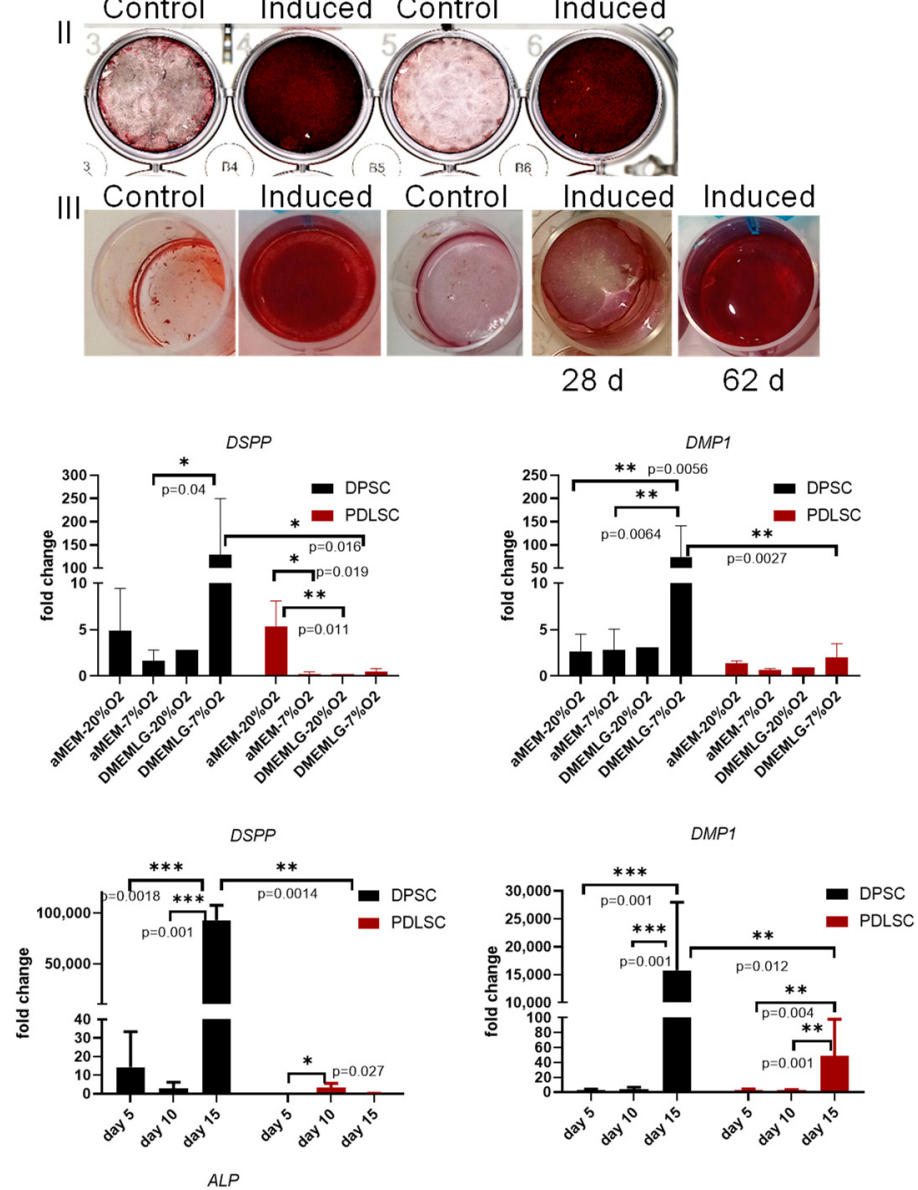

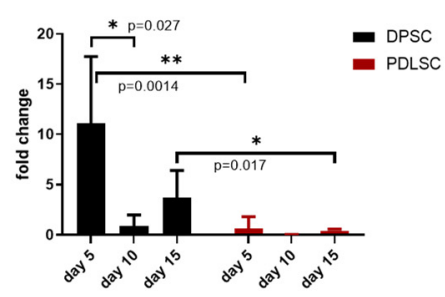

Figure 4. DPSC and PDLSC differentiation after osteogenic induction. (a) the rate of appearance of the first visible calcifications, the day when calcifications were revealed is plotted on the $Y$-axis; (b) Alizarin staining of DPSC and PDLSC on days 19 (Panel I) and 28 (Panel II) after osteogenic induction. Panel III: a PDLSC sample with delayed differentiation. (c) Transcription of osteogenic and odontogenic markers (RUNX2, Dentin sialophosphoprotein DSPP, Dentin matrix acidic phosphoprotein $1 D M P 1$ ) after $72 \mathrm{~h}$ post-induction in different cell culture conditions. Cells were grown in different $\mathrm{O}_{2}$ concentration (hypoxia $\left(7 \% \mathrm{O}_{2}\right)$ and normoxia, $\left.20 \% \mathrm{O}_{2}\right)$ and the osteogenic factors were added either in low glucose DMEM or in $\alpha$-MEM. (d) Transcription of osteogenic and odontogenic markers (RUNX2, alkaline phosphatase ALP, DSPP, DMP1) during 15 days of differentiation in hypoxia. $Y$-axis—fold change. Reference gene $-G A P d H .{ }^{*}-p<0.05{ }^{* *}-p<0.01,{ }^{* * *}-p<0.001$; the exact $p$-values are also shown.

Thus, both DPSC and PDLSC were capable of osteogenic differentiation. However, DPSC differentiated into the odontoblastic direction. 


\subsection{PDLSCs and DPSCs Have Different Proteomics Profiles during Osteogenic Differentiation}

The results of our experiments obtained by qPCR, immunocytochemistry, and microscopy confirmed that DPSC and PDLSC, despite their morphological similarity, represent two different populations of dental stem cells with different functionality. A proteomic comparison was performed for better evaluation of the difference and biological functions of DPSC and PDLSC. For proteomic comparison, we performed shotgun (LC-MS/MS with ion mobility) and gel-based (two-dimensional difference gel electrophoresis; 2D DIGE) analysis of the same samples of PDLSC and DPSC in control and on the 10th day after induction of osteogenic differentiation.

\subsubsection{Shotgun Proteomics}

By the shotgun proteomics analysis using tandem-mass-spectrometry with ion mobility in PASEF mode, we identified 2660 protein groups that have at least two unique peptides and were represented in both biological replicates at least in one biological group. Only 1521 of such proteins were shared among all samples, while 1139 of proteins were unique for some of compared groups, e.g., 422 of proteins were unique for PDLSC and only 96 for DPSC (Figure 5a). The list of accession numbers of proteins unique for PDLSC and DPSC is given in the Supplemented Materials (File S1).

(a)

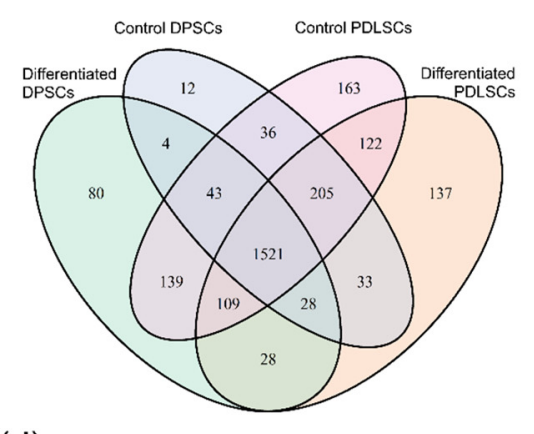

(d)

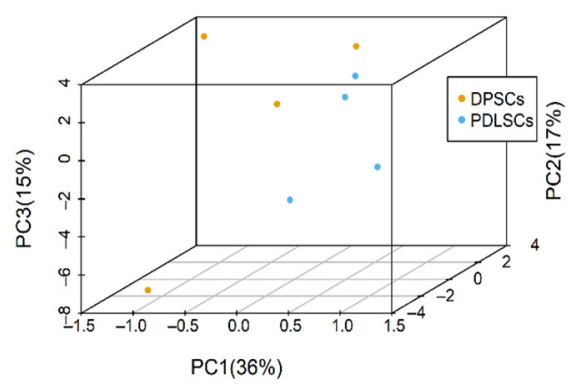

(b)

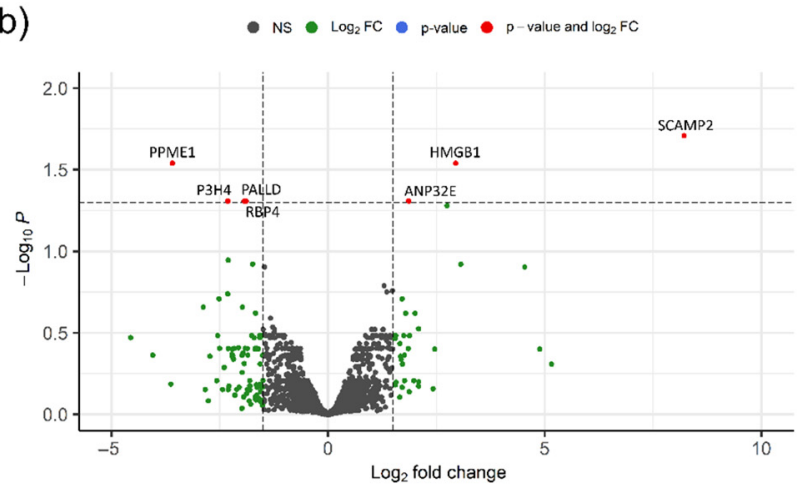

(c)

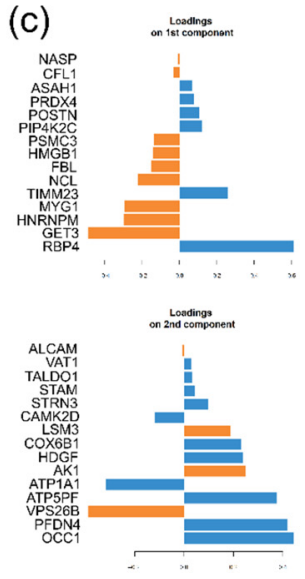

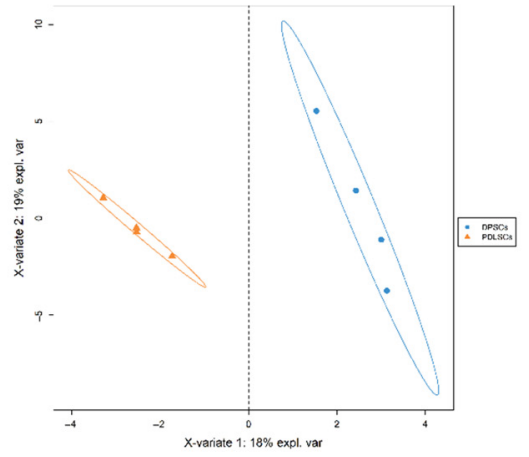

Figure 5. Comparison of proteomics profiles of PDLSC and DPSC during osteogenic differentiation. (a) Venn diagram representing proteins unique for biological groups compared by shotgun proteomics. (b) Volcano plot representing differentially expressed proteins between DPSC and PDLC. Log2Fold Change-level of change in expression-Log10Plogarithm of $p$-value. Dotted lines cut off transcripts with $p$-value $<0.05$ and Log2Fold Change $>|1.5|$. (c) Ordination of DPSC and PDLSC by principal component analysis. Blue dots-DPSC, orange dots-PDLSC. (d) Classification of DPSC and PDLSC by sparse Partial Least Squares Discriminant Analysis (sPLS-DA). Blue circles-DPSC, orange triangles_PDLSC. Loadings on the 1st and 2nd component represent 15 proteins, which contribute the most to the respective components, the color represent in which of the group the mean of the protein is maximal. 
Enrichment analysis against GO biological process database (GO BP) revealed, that proteins, unique for differentiated DPSCs (80 proteins) are involved in protein transport $\left(p\right.$-Value $\left.=8.4 \times 10^{-3}\right)$, cytoskeleton organization $\left(p\right.$-Value $\left.=7.7 \times 10^{-4}\right)$, extracellular matrix organization $\left(p\right.$-Value $\left.=1.1 \times 10^{-2}\right)$, intracellular protein transport $\left(p\right.$-Value $\left.=2.1 \times 10^{-2}\right)$, cell-to-cell adhesion $\left(p\right.$-Value $\left.=3.3 \times 10^{-2}\right)$, regulation of focal adhesion assembly $\left(p\right.$-Value $\left.=2.6 \times 10^{-3}\right)$ and vesicle docking involved in exocytosis $\left(p\right.$-Value $\left.=6 \times 10^{-3}\right)$. According to these biological process, enrichment analysis against KEGG database revealed proteins associated with focal adhesion/regulation of actin cytoskeleton ( $p$-Value $=6.4 \times 10^{-3}$ and $7 \times 10^{-3}$, respectively) and endocytosis $\left(p\right.$-Value $\left.=5 \times 10^{-2}\right)$.

Control (undifferentiated) and differentiated DPSC together have only four unique proteins (HSPG2, SEC24A, TMEM106B, VNN1). All four of them were described in the extracellular vesicles and therefore might be associated with extracellular matrix organization. HSPG2 expression is activated in the dental pulp when orthodontic force is applied. The protein is important in repairing and remodeling ECM in tissue stroma and basement membrane [53].

Proteins specific for control (undifferentiated) PDLSC (163 proteins) are associated with many biological processes among which cell cycle and DNA replication (e.g., Cell cycle and DNA replication, KEGG, $p$-value $=9.2 \times 10^{-4}$ and $8.0 \times 10^{-5}$ ), splicing (e.g., mRNA splicing, via spliceosome, GO BP, $p$-Value $=3.6 \times 10^{-3}$ ), cell proliferation (e.g., positive regulation of cell proliferation, GO BP, $p$-Value $=8.3 \times 10^{-3}$ ) and negative regulation of apoptotic process $\left(\mathrm{GO} \mathrm{BP}, p\right.$-Value $\left.=2.10 \times 10^{-2}\right)$. Control PDLSC express a number of unique metabolic proteins involved in KEGG "Metabolic pathways" ( $p$-Value $=2.7 \times 10^{-2}$ ) with associated biological processes: purine ribonucleoside monophosphate biosynthetic process $\left(p\right.$-Value $\left.=5.6 \times 10^{-3}\right)$, nucleotide biosynthetic process $\left(p\right.$-Value $\left.=7.5 \times 10^{-3}\right)$, positive regulation of collagen biosynthetic process $\left(p\right.$-Value $\left.=1.7 \times 10^{-2}\right)$, response to nutrient $\left(p\right.$-Value $\left.=2.8 \times 10^{-2}\right)$, regulation of glucose transport $\left(p\right.$-Value $\left.=3.4 \times 10^{-2}\right)$, oxidationreduction process $\left(p\right.$-Value $\left.=3.7 \times 10^{-2}\right)$, response to nutrient $\left(p\right.$-Value $\left.=2.8 \times 10^{-2}\right)$, regulation of glucose transport $\left(p\right.$-Value $\left.=3.4 \times 10^{-2}\right)$, cellular response to retinoic acid $\left(p\right.$-Value $\left.=2.4 \times 10^{-2}\right)$ and cholesterol biosynthetic process $\left(p\right.$-Value $\left.=4.4 \times 10^{-2}\right)$. Finally, there are some proteins associated with signaling pathways and cell differentiation: wound healing $\left(p\right.$-Value $\left.=7.4 \times 10^{-5}\right)$, positive regulation of tyrosine phosphorylation of Stat3 protein $\left(p\right.$-Value $\left.=4.4 \times 10^{-2}\right)$, ATP-dependent chromatin remodeling $\left(p\right.$-Value $\left.=1.0 \times 10^{-3}\right)$, planar cell polarity pathway involved in neural tube closure $\left(p\right.$-Value $\left.=4.8 \times 10^{-3}\right)$, protein sumoylation $\left(p\right.$-Value $\left.=2.0 \times 10^{-2}\right)$, activation of GTPase activity $\left(p\right.$-Value $\left.=3.3 \times 10^{-2}\right)$, chromatin remodeling $\left(p\right.$-Value $\left.=4.0 \times 10^{-2}\right)$, peptidyltyrosine phosphorylation $\left(p\right.$-Value $\left.=4.7 \times 10^{-2}\right)$. Among these proteins WNT5A, WNT5B HDAC1, HDAC2, AKT2 should be emphasized as proteins associated with osteogenic differentiation (more information in the discussion section).

Differentiated PDLSC have 137 unique proteins involved in apoptosis (e.g., apoptotic process, GO BP, $p$-Value $\left.=2.4 \times 10^{-3}\right)$ and cell-cell adhesion $\left(\mathrm{GO} \mathrm{BP}, p\right.$-Value $\left.=4.9 \times 10^{-2}\right)$

Interestingly, RUNX2 - the main transcriptional factor of osteogenic differentiationwas found only in both control and differentiated PDLSC, while it was under detection range in all DPSC samples. The results differed from those obtained by qPCR (Figure 4c,d) probably due to DDA mass spectrometry limitations, delayed expression of transcribed mRNA or post-translational regulation of RUNX2. Another possible explanation is posttranscriptional downregulation of RUNX2 during osteogenic differentiation in the time-point selected for proteomics analysis (10th day) [54]. A similar pattern was observed for Akt1 and CDK1—proteins associated with cell differentiation decisions and osteogenic differentiation.

After qualitative analysis, only proteins found in more than $85 \%$ of samples were used for quantitative analysis (1830 proteins). We started from the ordination of samples by Principal Component Analysis (PCA) and classification by sparse Partial Least Squares Discriminant Analysis (sPLS-DA). Both methods revealed two distinct clusters of DPSC and PDLSC - these cells have different proteomic profiles before and during osteogenic differ- 
entiation (Figure $5 \mathrm{c}, \mathrm{d}$ ). Using sPLS-DA we found 30 proteins with the higher contribution to the observed classification pattern, 15 of which were contributed to the first component with the biggest resolution between DPSC and PDLSC (Figure 5c). Thus, we might indicate proteins with higher abundance in DPSC (ASAH1, PRDX4, POSTN, PIP4K2C, TIMM23, RBP4) and in PDLSC (NASP, CFL1, PSMC3, HMGB1, FBL, NCL, MYG1, HNRNPM, GET3).

Further, we performed differential expression analysis and compared all DPSC and PDLSC and found seven differentially expressed genes (DEGs) with Fold change higher than 1.5 and adjusted $p$-value less than 0.05 (Figure $5 b$ ). Four of DEGs are more abundant in DPSC (PPME1, P3H4, RBP4, PALLD) and three more abundant in PDLSC (SCAMP2, HMGB1, ANP32E). Two of the proteins were identified by sPLS-DA and differential expression analysis: RBP4 (more abundant in DPSC) and HMGB1 (more abundant in PDLSC).

\subsubsection{Gel-Based Proteomics}

Gel-based and shotgun proteomics are known to be complementary. Thus, in addition to shotgun proteomics, we performed gel-based analysis by 2D DIGE. Among 240 spots identified in electropherograms we found 10 differentially expressed protein spots marked in Figure 6 (fragments of electropherograms with comparison of marked spots are presented in the supplementary Figure S1; full raw electrophoregrams are available on ProteomeXchange, PXD027719).

These 10 protein spots were identified by MS/MS (Table 3). Spots number 1, 2, 8, 9, and 10 were downregulated during differentiation of both cell types. Spots 1 and 2 were identified as collagen alpha-1(I) and alpha-2(I) chains respectively; spots number 8 and 10 as Tropomyosin beta and alpha- 1 chains; spot 9 as Annexin A2.

Several cell-type-specific proteins were also identified. Spots number 5-7, identified as vimentin, were upregulated in differentiated PDLSC, while spots 3 and 4 were specific for differentiated DPSC. Spot 3 was identified as Prelamin-A/C, but we found at least four proteins reproducibly identified in spot 4: Annexin A6, Heat shock cognate $71 \mathrm{kDa}$ protein, Cytoskeleton-associated protein 4, Lamin-B2 (Table 3).

By the shotgun proteomics, we found dozens of cell-type-specific proteins (Figure 5) which involved in many biological processes. PDLSCs had more unique proteins compared to DPSCs. Most of the PDLSCs-specific proteins were associated with the cell cycle, proliferation, and metabolism. The data are in good accordance with the higher proliferative and migration activity of PDLSCs while DPSCs might be considered as more committed to ECM production. DPSCs-specific proteins are associated with protein transport, extracellular matrix organization, exocytosis, etc.

Nevertheless, RUNX2-a key master protein of osteogenic differentiation was exclusively found in both control and differentiated PDLSCs while it was out of a detection range in all DPSCs samples. Thus, phenomena might be an artifact of DDA proteomics or have biological nature. To evaluate possible differences in RUNX2 regulation we analyzed protein interaction networks (by String database; string-db.org; accessed on 20 July 2021) of proteins capable of interaction with RUNX2. We analyzed proteins unique for PDLSCs in control (overall unique proteins plus proteins unique for control PDLSCs; Figure 7a) and after induction of osteogenic (overall unique proteins plus proteins unique for differentiated PDLSCs; Figure 7b). Surprisingly we found a relatively small number of proteins interacting with RUNX2. Moreover, most interactions were predicted by indirect evidence. CDK1, AKT1, EGFR, and some other proteins were able to interact with dozens of proteins in the tested dataset (data not shown). Thus, RUNX2 is in the periphery of the PDLSCs-specific protein interaction network. 
(a)

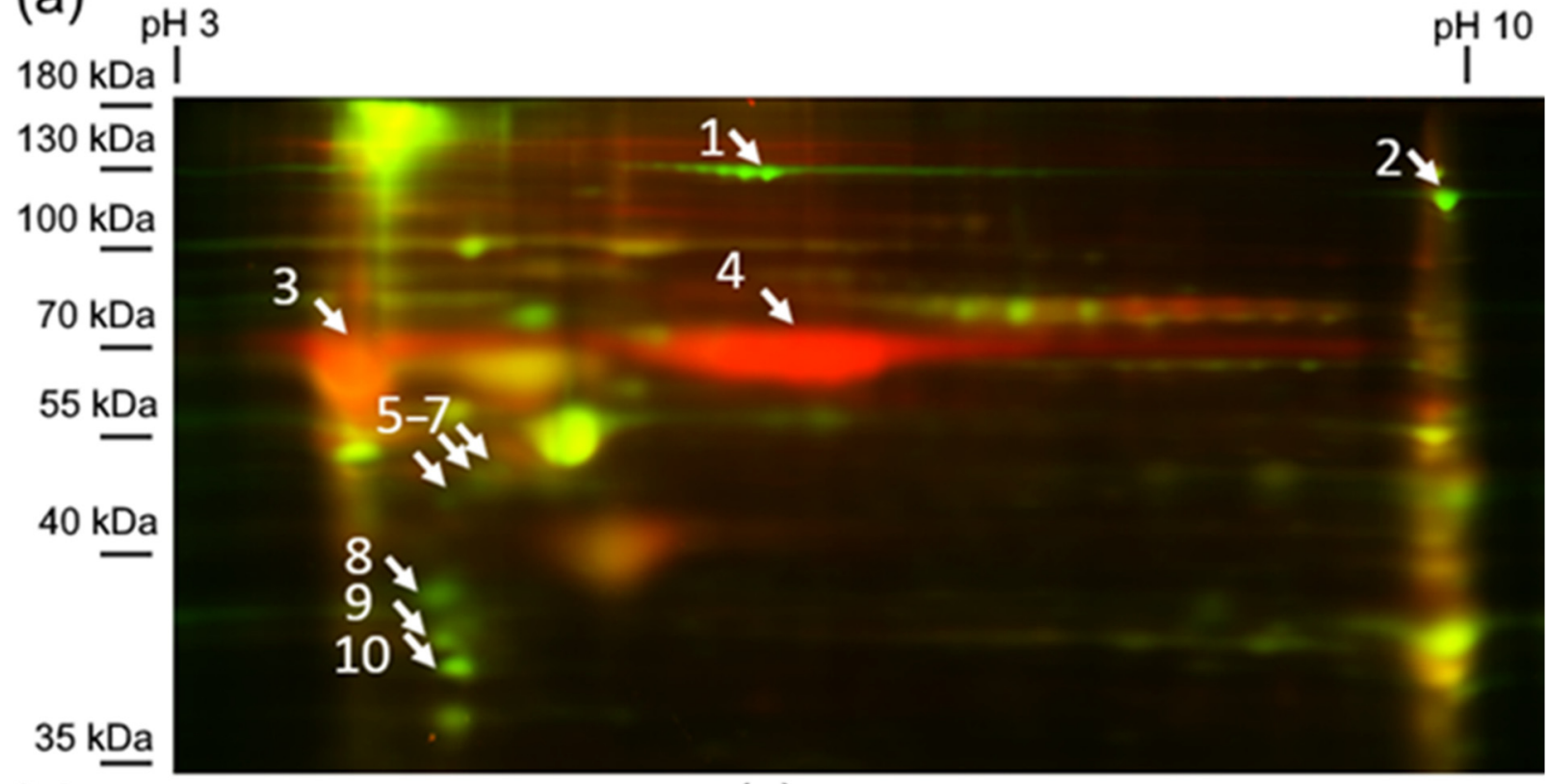

(b)
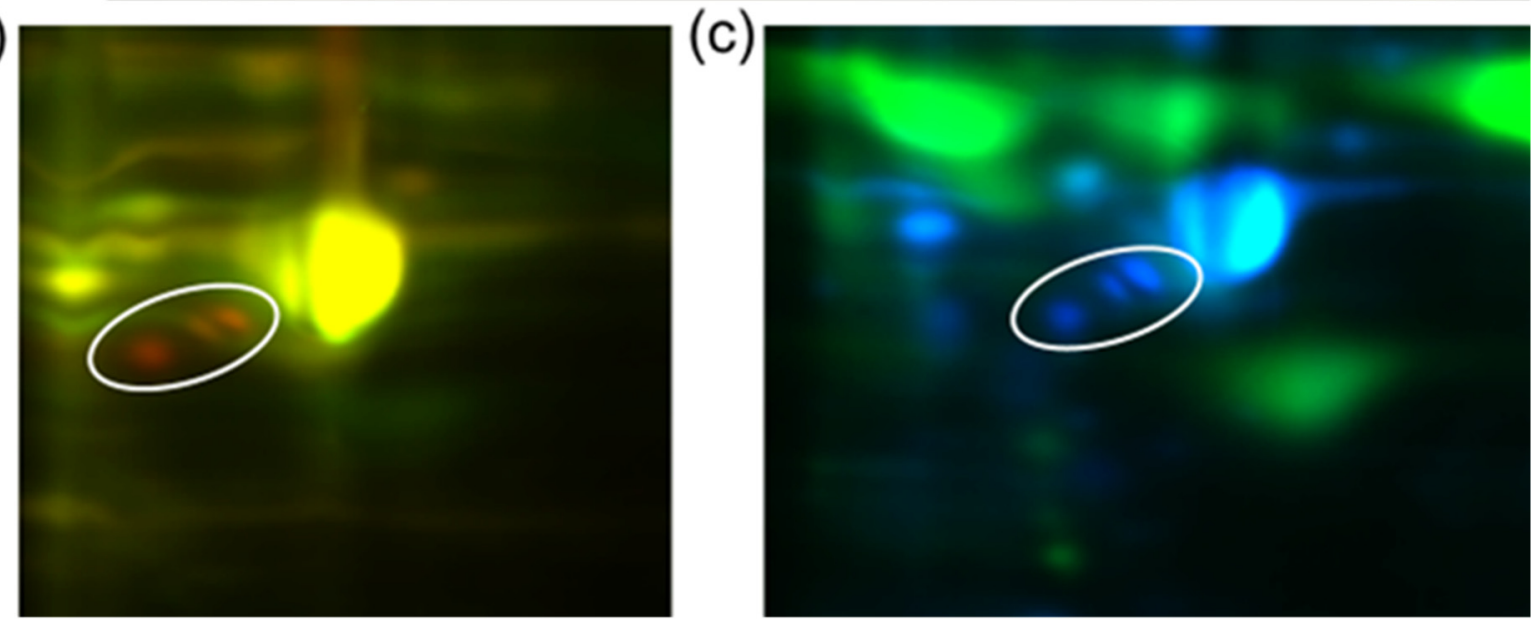

Figure 6. Differentially expressed proteins identified by 2D-DIGE. (a) Electropherogram corresponding to the overlapping of Cy fluorochrome channels of control (green) and differentiated (red) DPSC. Numbers marked differentially expressed protein spots reproducibly presented in both biological replicates of some of the biological groups. (b) Electropherogram corresponding to the overlapping of Cy fluorochrome channels of control (green) and differentiated (red) PDLSC. White circle-protein spots 5-7, specific for differentiated PDLSC. (c) Electropherogram corresponding to the overlapping of Cy fluorochrome channels of differentiated DPSC (green) and differentiated (blue) PDLSC. White circle-protein spots 5-7, specific for differentiated PDLSC.

Table 3. Results of MS/MS identification of protein spots from Figure 6. The best scores from at least two technical replicates are presented.

\begin{tabular}{|c|c|c|c|c|c|c|c|}
\hline $\begin{array}{c}\text { № of Protein } \\
\text { Spot }\end{array}$ & $\begin{array}{c}\text { UniProt } \\
\text { Accession }\end{array}$ & Protein Name & $\begin{array}{c}\text { Peaks Xpro } \\
\text { Dentification } \\
\text { Probability } \\
(-10 \operatorname{lgP})\end{array}$ & $\begin{array}{c}\text { Protein } \\
\text { Coverage, } \%\end{array}$ & $\begin{array}{l}\text { Number of } \\
\text { Unique } \\
\text { Peptides }\end{array}$ & MW, kDa & Comment \\
\hline 1 & P02452 & $\begin{array}{l}\text { Collagen } \\
\text { alpha-1(I) } \\
\text { chain }\end{array}$ & 525.21 & 66 & 69 & 138,942 & $\begin{array}{l}\text { Downregulated in } \\
\text { differentiation of } \\
\text { both cell types }\end{array}$ \\
\hline 2 & P08123 & $\begin{array}{l}\text { Collagen } \\
\text { alpha-2(I) } \\
\text { chain }\end{array}$ & 451.38 & 28 & 26 & 129,314 & $\begin{array}{c}\text { Downregulated in } \\
\text { differentiation of } \\
\text { both cell types }\end{array}$ \\
\hline
\end{tabular}


Table 3. Cont

\begin{tabular}{|c|c|c|c|c|c|c|c|}
\hline $\begin{array}{c}\text { № of Protein } \\
\text { Spot }\end{array}$ & $\begin{array}{c}\text { UniProt } \\
\text { Accession }\end{array}$ & Protein Name & $\begin{array}{l}\text { Peaks Xpro } \\
\text { Dentification } \\
\text { Probability } \\
\text { (-10lgP) }\end{array}$ & $\begin{array}{c}\text { Protein } \\
\text { Coverage, \% }\end{array}$ & $\begin{array}{l}\text { Number of } \\
\text { Unique } \\
\text { Peptides }\end{array}$ & MW, kDa & Comment \\
\hline 3 & P02545 & Prelamin-A/C & 255.33 & 31 & 23 & 74,140 & $\begin{array}{l}\text { Upregulated in } \\
\text { differentiated } \\
\text { DPSC }\end{array}$ \\
\hline \multirow{4}{*}{4} & P08133 & Annexin A6 & 416.45 & 71 & 51 & 75,873 & \multirow{4}{*}{$\begin{array}{l}\text { Upregulated in } \\
\text { differentiated } \\
\text { DPSC }\end{array}$} \\
\hline & P11142 & $\begin{array}{c}\text { Heat shock } \\
\text { cognate } 71 \mathrm{kDa} \\
\text { protein }\end{array}$ & 393.45 & 59 & 30 & 70,898 & \\
\hline & Q03252 & $\begin{array}{l}\text { Cytoskeleton- } \\
\text { associated } \\
\text { protein } 4\end{array}$ & 337.48 & 55 & 29 & 66,023 & \\
\hline & Q07065 & Lamin-B2 & 320.73 & 47 & 27 & 69,948 & \\
\hline 5 & P08670 & Vimentin & 403.16 & 75 & 43 & 53,652 & $\begin{array}{l}\text { Upregulated in } \\
\text { differentiated } \\
\text { PDLSC }\end{array}$ \\
\hline 6 & P08670 & Vimentin & 352.72 & 68 & 40 & 53,652 & $\begin{array}{l}\text { Upregulated in } \\
\text { differentiated } \\
\text { PDLSC }\end{array}$ \\
\hline 7 & P08670 & Vimentin & 396.21 & 71 & 70 & 53,652 & $\begin{array}{l}\text { Upregulated in } \\
\text { differentiated } \\
\text { PDLSC }\end{array}$ \\
\hline 8 & P07951 & $\begin{array}{l}\text { Tropomyosin } \\
\text { beta chain }\end{array}$ & 299.34 & 53 & 6 & 32,851 & $\begin{array}{c}\text { Downregulated in } \\
\text { differentiation of } \\
\text { both cell types }\end{array}$ \\
\hline 9 & P07355 & Annexin A2 & 283.10 & 37 & 12 & 38,604 & $\begin{array}{c}\text { Downregulated in } \\
\text { differentiation of } \\
\text { both cell types }\end{array}$ \\
\hline 10 & P07951 & $\begin{array}{l}\text { Tropomyosin } \\
\text { alpha-1 chain }\end{array}$ & 284.12 & 43 & 15 & 32,709 & $\begin{array}{l}\text { Downregulated in } \\
\text { differentiation of } \\
\text { both cell types }\end{array}$ \\
\hline
\end{tabular}

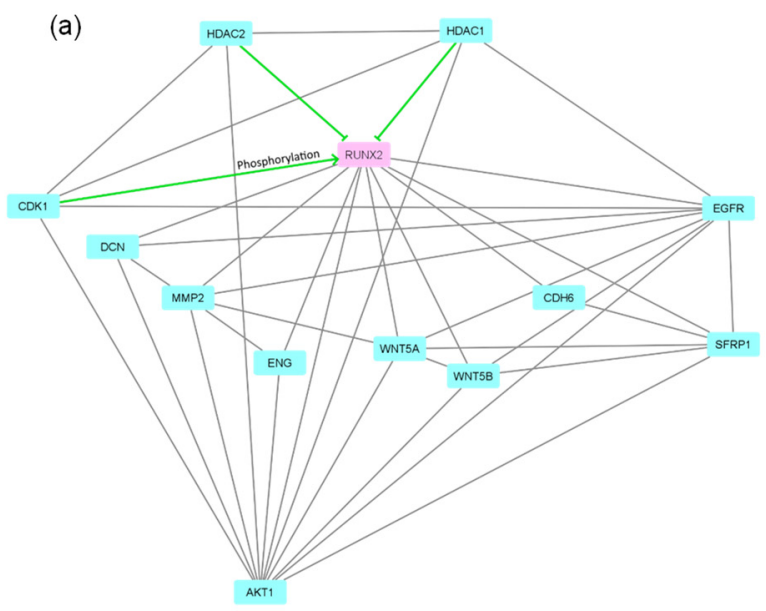

(b)

Figure 7. String interaction networks of proteins interacting with RUNX2 among PDLSCs-specific proteins founded in control cells (a) and cells after induction of osteogenic differentiation (b). Greenprotein-protein interactions with experimental evidence. The image was obtained in the Cytoscape software v. 3.8.1 (Cytoscape Consortium; https: / / cytoscape.org/; accessed on 21 July 2021).

According to mass-spectrometry data, the proteomes of DPSC and PDLSC are different. PDLSC proteomes are enriched for proteins, responsible for cell cycle control, proliferation, secretion. 


\section{Discussion}

The present study compared the morphological properties, pluripotency markers expression, osteogenic/odontogenic potential, and proteomes of PDLSC and DPSC. The two populations differed in each of these parameters. We used DPSC-PDLSC pairs obtained from the same donor. Paired observations led us to the conclusions that the variability between donors is high, though general trends are similar in most of the pairs. In our study, DPSC were characterized as relatively slow-proliferating cells (especially at the beginning of in vitro expansion) with the MSC set of surface markers, low-level expression of OCT4 and the ability to differentiate into the odontogenic direction. PDLSC proliferated faster, did not express OCT4, but were positive for SSEA-4 and were capable for general osteogenic but not odontogenic differentiation.

Some authors report that PDLSC proliferate more slowly than DPSC $[6,8,55]$, while others describe slow, fast, and intermediate proliferation rates in different samples of PDLSC [56]. The existence of fast and slowly proliferating DPSC subpopulations has also been reported [57]. All these studies have been carried out on cells grown in normoxia $\left(20 \% \mathrm{O}_{2}\right)$ that is a non-physiological $\mathrm{O}_{2}$ concentration for cells in primary cultures. For most tissues, the physiological $\mathrm{O}_{2}$ concentration does not exceed 8\% [58,59]. MSC grown permanently in "physiological hypoxia" conditions have increased proliferation rate, OCT4 expression, chondrogenic potential [59]. A similar tendency has been demonstrated for dental stem cells though some of the authors admit our limited knowledge on this issue [8,60-62]. Therefore, in our studies, the slow rate of DPSC proliferation might be explained by the greater survival of the slow-proliferating clones at the physiological hypoxia.

The set of DPSC and PDLSC surface markers corresponded to the set of markers of MSC. However, in cells of both origins, a CD117 (c-kit) positive subpopulation of stem cells was identified (Table 2). CD117-positive DPSC are considered as less differentiated subpopulation $[63,64]$. Moreover, some of these DPSC cells expose CD34 on their surface. These cells showed a slower proliferation, gradual loss of stemness, early cell senescence, and apoptosis [57]. c-Kit is a marker of dental pulp progenitor cells and is involved in DPSC self-renewal and stemmness maintenance [65-67]. The protein is also expressed in PDLSC [66]. On the other hand, staining for CD117 occurs in a variety of tumor types, although strong staining is present mainly in mast cell disease and gastrointestinal stromal tumors, for which CD117 is the preferred marker [68,69]. Given the c-kit as well the Oct-4 expression along with the fast proliferation, the issue of biological safety of dental stem cells must be thoroughly studied.

NES (Nestin) gene was transcribed at a significantly higher level in DPSC than in PDLSC in all the donors (Figure 2). DPSC are known to derive from neural crest cells and are inclined to differentiate into neural cells [36]. DPSC have a higher positive ratio for neural markers such as NES, GFAP, and s100-beta than other kinds of MSC [5,36,70,71]. However, PDLSC have different embryonic origin: dental pulp is formed from dental papilla while PDLSC originate from dental follicle cells [7,72]. NES is considered as a marker not only of DPSC but also of odontoblasts and denticle lining cells, suggesting that denticle cells and odontoblast-like cells may derive from the same pulp stem cell populations [35]. Taking this into account, a greater tendency of DPSC to odontogenic differentiation in comparison with the PDLSC (Figure 4c,d) can be expected.

In our study, staining with an OCT4 antibody revealed the protein only in DPSC nuclei while SSEA-4 positive signals were revealed in the PDLSC cytoplasm only (Figure 3b). According to quantification data, the OCT4 gene transcription level was very low in DPSC and PDLSC as compared to embryonic stem cells of blastocysts: transcription in dental stem cells varied from 0.0003 to 0.002 of the level in blastocysts (Figure 3a). The low quantity of transcripts might explain the absence of PDLSC staining with the AB against OCT4the quantity of the protein expressed from the mRNA is probably below the detection limit. OCT4, also known as POU5F1, is a nuclear transcription factor that is necessary for the maintenance of the pluripotency of stem cells and primordial germ cells [73]. It is 
also a diagnostic marker of some pluripotential germ cell tumors as dysgerminoma and embryonal carcinoma and for in situ germ cell neoplasia such as intratubular germ cell neoplasia in the testis and gonadoblastoma in dysgenetic gonads [68]. There are tumors in which the expression of the OCT4 gene is increased, but its activation is associated with the movement of the gene under the active promoter, but not with the mechanisms involved in embryonic cells [74]. Ectopic expression of OCT4 in certain somatic cells has been associated with active dedifferentiation [75] or some other effect e.g., atheroprotection [39]. It is also transcribed in MSC at low passages [76]. This finding suggests that it plays a key role not only in maintaining the pluripotency of embryonic stem cells but also in self-renewal and protection against apoptosis of somatic stem cells and tumor-initiating cells. However, researchers from the Dr. R. Jaenish group argued against the role of OCT4 in self-renewal, proliferation and pluripotency maintenance [77]. The controversy might be explained by the fact that OCT4 generate three main protein isoforms: OCT4A, OCT4B [78], and OCT4B1 [79]. Most studies have focused on the OCT4A as a transcription factor responsible for stemness properties. The 360-amino-acid OCT4A protein is the gatekeeper to pluripotency, the other variants have been associated with antiapoptotic effects and stress responses, but they do not share the pluripotency characteristics of OCT4A [80]. The OCT4 primer set used in this study detects all main isoforms of the transcripts [24]. In our study, the level of OCT4 transcription was 1000-10,000-fold less than in blastocyst's cells when probed by qPCR. These results suggested that either a percentage of pluripotent stem cells was very low in the samples or, if the protein was present in many nuclei but in low quantities (Figure 3), that it can have other functions in dental stem cells. OCT4 is involved in the maintenance of MSC characteristics in DPSC [81]. The depletion of OCT4 decreased the proliferation and osteogenic properties of DPSC, while overexpression of OCT4 enhanced the proliferation rate and osteogenic/chondrogenic/adipogenic potential of DPSC. The expression of OCT4, SSEA-4 and other ES markers in human PDLSC were described earlier [82,83]. The exposition of SSEA-4 on the cell surface is considered as one of the markers of pluripotent cells [43] suitable for cell sorting when OCT4 staining is not possible [44-46]. Nevertheless, it is also expressed in a line of immortalized bone marrow MSC and in a subpopulation (1-2\%) of non-transformed primary bone marrow MSC [84]. SSEA-4 is known as a marker of PDLSC [9]. We demonstrated for the first time that DPSC and PDLSC are different in their pluripotency markers levels. Besides, transcription and expression of OCT4 and SSEA-4 are not always coupled in the same cell.

In our study, both DPSC and PDLSC were capable of osteogenic differentiation and deposition of Alizarin Red stained calcifications. However, it has been shown that extracellular matrix produced by different population of dental stem cells varies in its composition though all variations were stained by Alizarin Red [10]. Our data prove the difference between two populations of dental stem cells in their mechanisms of osteogenic differentiation. We observe odontoblastic markers only in samples differentiated from DPSC. DPSC are known to be capable of odontoblastic differentiation $[14,15,55]$ and are also responsible for tertiary dentin formation [12] and denticle biomineralization [35]. PDLSC mechanism of osteogenic differentiation is not the same as in DPSC. They can differentiate into cementoblasts, whose biological function is cementogenesis aimed to provide the anchoring of the periodontal ligament to the tooth [12]. We have demonstrated earlier that human PDLSC differentiation after osteogenic induction is promoted by Notch [85], while DPSC odontoblastic differentiation is inhibited by this pathway [86]. Nevertheless, PDLSC are involved in oral cavity regeneration processes. Prof. T. Inoue's group demonstrated that it was PDLSC but not mesenchymal stem cells and hematopoietic stem cells of the bone marrow that were involved in the regeneration of the periodontium [87]. Some authors have observed odontoblastic differentiation of PDLSC [11]. In our work, we tried to exclude the mixing of PDLSC and DPSC - a tooth was treated with ethanol to kill the cells on its surface (residual ligament, apical papilla) before opening the pulp chamber. In such conditions, we did not observe odontogenic differentiation of PDLSC. 
To study further the overall functional similarity and differences of DPSCs and PDLSCs we performed their untargeted proteomics analysis by two complementary approaches: 2D-DIGE (gel-based proteomics) and Label-free shotgun proteomics with ion mobility. We found major differences between differentiated DPSCs and PDLSCs by both methods (Figures 5 and 6). DPSCs and PDLSCs form distinct clusters on both PCA (ordination) and sPLS-DA (classification), which confirms our assumption of physiological differences existing between DPSCs and PDLSCs before and after osteogenic differentiation. We identified several groups of cell-type-specific proteins. In the two-dimensional electrophoresis, we identified vimentin as exclusively upregulated during osteogenic differentiation of PDLSCs and Prelamin-A/C, Lamin-B2, Annexin A6, Heat shock cognate $71 \mathrm{kDa}$ protein and Cytoskeleton-associated protein 4 as unique for differentiated DPSCs.

Vimentin is a mesenchymal intermediate filament protein. This protein has structure function, but it is also known to be involved in cell proliferation and differentiation $[88,89]$. Interesting that we might detect at least three spots identified as vimentin (Figure 6) - these protein spots probable correspond to different vimentin isoforms or specific post-translational modification, but we have not found significant differences in MS/MS identification of these spots.

Lamins are nuclear intermediate filaments tightly associated with mechanotransduction influenced cell differentiation and migration [90]. Particularly, the level of Lamins-A/C is known to be increased during osteogenic differentiation [91]. The higher abundance of vimentin and the lower level of lamins in PDLSCs might be associated with the higher migratory and proliferative activity of these cells. In opposite, DPSCs seems to be less proliferative, but secreting more ECM. According to these, they have a higher amount of lamins, Heat shock cognate $71 \mathrm{kDa}$ protein (protein quality control), Cytoskeletonassociated protein 4 (antiproliferative receptor in epithelial cells, structure component of endoplasmic reticulum) and Annexin A6 (involved in exocytosis and ECM mineralization).

By the shotgun proteomics, we found dozens of cell-type-specific proteins (Figure 5), which are involved in many biological processes. PDLSCs have more unique proteins compared to DPSCs. Most of the PDLSCs-specific proteins are associated with the cell cycle, proliferation and metabolism which is in good accordance with the higher proliferative and migration activity of PDLSCs while DPSCs might be considered as more committed to ECM production. This observation can explain our data about faster proliferation of PDLSC as compared to DPSC. DPSCs-specific proteins are associated with protein transport, extracellular matrix organization, exocytosis, etc.

RUNX2 - a key master protein of osteogenic differentiation—was exclusively found in both control and differentiated PDLSCs while it was out of a detection range in all DPSCs samples. RUNX2 is known to be unnecessary for osteogenic differentiation of dental follicle cells [92]. Moreover, in the tumor cells, RUNX2 is known to be associated with increased cell migration and proliferation, but not with osteogenic differentiation $[93,94]$. Particularly, melanoma cells with RUNT-deleted form of RUNX2 have reduced proliferation, increased apoptosis, and reduced EMT [94]. Finally, it was shown that RUNX2 regulated osteoblast proliferation and was necessary for normal cell cycle progression [95]. Thus, the presence of RUNX2 in both control and differentiated PDLSCs might be interpreted in the context of higher migratory and proliferative activity of PDLSCs. In DPSC, RUNX2 is transcribed though the level of transcription strongly depended on cell culture conditions (Figure $4 \mathrm{c}, \mathrm{d}$ ). Nevertheless, the protein was not detected by mass-spectrometry in any DPSC samples. It has been demonstrated that the effect of RUNX2 during odontoblast differentiation is stage-dependent. RUNX2 inhibits odontoblast terminal differentiation and induces transdifferentiation of odontoblasts to osteoblasts at the late cell differentiation stage [96-98]. Therefore, we suggest that the RUNX2 gene can be transcribed in DPSC but the mRNA translation might be delayed or stopped. The post-translational regulation of this protein [54] may also be an important factor. 


\section{Conclusions}

Our results prove that DPSC and PDLSC are different in their biology and therapeutic potential: DPSC are a good candidate for osteogenic or bone-replacement cellseeded medicines while fast proliferating PDLSC are a prospective candidate for other cell products.

Supplementary Materials: The following are available online at https:/ /www.mdpi.com/article/ 10.3390/biomedicines9111606/s1, File S1: Accesion No of identified proteins, Figure S1: Fragments of raw electropherograms corresponding to protein spots described in the main text of Kotova et al., 2021.

Author Contributions: Conceptualization, N.I.E. and A.B.M.; methodology, A.A.L., J.A.D. and N.I.E.; software, A.A.L., A.L.S. and V.Y.S.; validation, N.A.R. and A.L.S.; formal analysis, A.A.L.; investigation, A.V.K., J.A.D., P.K., N.I.E. and N.A.R.; resources, J.A.D.; data curation, A.A.L., V.Y.S. and A.V.K.; writing-original draft preparation, A.V.K., A.A.L. and N.I.E.; writing-review and editing, N.I.E., A.B.M. and A.A.L.; visualization, A.V.K., A.A.L. and N.I.E.; supervision, N.I.E. and A.B.M.; project administration, N.I.E. and A.B.M.; funding acquisition, N.I.E., A.B.M. and J.A.D. All authors have read and agreed to the published version of the manuscript.

Funding: The work was supported by state assignment No. 056-00056-19-00 (theme No AAAA-A19119053190037-1)/Ministry of Health of Russian Federation. The proteomic part of the work carried out by A.B.M., A.A.L., P.K. and V.Y.S. was supported by Russian Foundation for Basic Research (grant No 19-29-04082).

Institutional Review Board Statement: All procedures performed in the study involving human beings complied with the ethical standards of the institutional and/or national research ethics committee and the 1964 Helsinki Declaration and its subsequent changes or comparable ethical standards (Declaration of Helsinki: Ethical Principles for Medical Research Involving Human Sub-jects, including amendments made by the 64th Meeting of World Medical Association in Fortaleza, Brazil, October 2013). An informed written consent was obtained from each of the participants enrolled in the study (or his/her parents for underage children and blastocysts). The ethical committee of Mechnikov North-Western State Medical University approved isolation and expansion of primary cultures from PDLSC and DPSC (ethical vote No 12, date of issue 12 December 2019). The local ethical committee of Ava-Peter-Scandinavia assisted reproduction clinics approved the usage of blastocysts (ethical vote \#2/23-10-2018, date of issue 23/10/2018).

Informed Consent Statement: Informed consent was obtained from all subjects involved in the study.

Data Availability Statement: The mass spectrometry proteomics data have been deposited to the ProteomeXchange Consortium via the PRIDE [25] partner repository with the dataset identifier PXD027719 and 10.6019/PXD027719.

Acknowledgments: The authors thank the patients, hospitals, clinicians, and research staff at participating institutions for their support of the study. Shotgun and 2D DIGE proteomics were performed in the research resource center «Molecular and cell technologies» of St. Petersburg State University Research Park. This work could not be done without the permanent assistance of G.I. Stein and M.L. Vorobiev from the confocal microscopy and imaging group of the Cell Technologies Centre (Institute of Cytology, RAS). We are very grateful to T.L. Zolina and N.A. Klementieva for their help in dental stem cell culture work.

Conflicts of Interest: The authors declare no conflict of interest.

\section{References}

1. Sharpe, P.T. Dental mesenchymal stem cells. Development 2016, 143, 2273-2280. [CrossRef] [PubMed]

2. Pisciotta, A.; Bertoni, L.; Vallarola, A.; Bertani, G.; Mecugni, D.; Carnevale, G. Neural crest derived stem cells from dental pulp and tooth-associated stem cells for peripheral nerve regeneration. Neural Regen. Res. 2020, 15, 373-381. [CrossRef]

3. Pispa, J.; Thesleff, I. Mechanisms of ectodermal organogenesis. Dev. Biol. 2003, 262, 195-205. [CrossRef]

4. Zeuner, M.-T.; Didenko, N.N.; Humphries, D.; Stergiadis, S.; Morash, T.M.; Patel, K.; Grimm, W.-D.; Widera, D. Isolation and Characterization of Neural Crest-Derived Stem Cells from Adult Ovine Palatal Tissue. Front. Cell Dev. Biol. 2018, 6, 39. [CrossRef] [PubMed] 
5. Widera, D.; Grimm, W.; Moebius, J.M.; Mikenberg, I.; Piechaczek, C.; Gassmann, G.; Wolff, N.A.; Thévenod, F.; Kaltschmidt, C.; Kaltschmidt, B. Highly Efficient Neural Differentiation of Human Somatic Stem Cells, Isolated by Minimally Invasive Periodontal Surgery. Stem Cells Dev. 2007, 16, 447-460. [CrossRef] [PubMed]

6. Navabazam, A.R.; Nodoshan, F.S.; Sheikhha, M.H.; Miresmacili, S.M.; Solcimani, M.; Fesahat, F. Characterization of mesenchymal stem cells from human dental pulp, preapical follicle and periodontalligament. Iran. J. Reprod. Med. 2013, 11, $235-242$.

7. Zhou, T.; Pan, J.; Wu, P.; Huang, R.; Du, W.; Zhou, Y.; Wan, M.; Fan, Y.; Xu, X.; Zhou, X.; et al. Dental Follicle Cells: Roles in Development and Beyond. Stem Cells Int. 2019, 2019, 9159605. [CrossRef]

8. Zhou, Y.; Fan, W.; Xiao, Y. The Effect of Hypoxia on the Stemness and Differentiation Capacity of PDLC and DPC. BioMed Res. Int. 2014, 2014, 890675. [CrossRef] [PubMed]

9. Fukushima, H.; Kawanabe, N.; Murata, S.; Ishihara, Y.; Yanagita, T.; Balam, T.; Yamashiro, T. SSEA-4 is a Marker of Human Deciduous Periodontal Ligament Stem Cells. J. Dent. Res. 2012, 91, 955-960. [CrossRef]

10. Volponi, A.A.; Gentleman, E.; Fatscher, R.; Pang, Y.; Gentleman, M.M.; Sharpe, P.T. Composition of Mineral Produced by Dental Mesenchymal Stem Cells. J. Dent. Res. 2015, 94, 1568-1574. [CrossRef] [PubMed]

11. Son, Y.-B.; Kang, Y.-H.; Lee, H.-J.; Jang, S.-J.; Bharti, D.; Lee, S.-L.; Jeon, B.-G.; Park, B.-W.; Rho, G.-J. Evaluation of odonto/osteogenic differentiation potential from different regions derived dental tissue stem cells and effect of $17 \beta$-estradiol on efficiency. BMC Oral Health 2021, 21, 15. [CrossRef]

12. Li, B.; Ouchi, T.; Cao, Y.; Zhao, Z.; Men, Y. Dental-Derived Mesenchymal Stem Cells: State of the Art. Front. Cell Dev. Biol. 2021, 9 , 654559. [CrossRef]

13. Chalisserry, E.; Nam, S.Y.; Park, S.H.; Anil, S. Therapeutic potential of dental stem cells. J. Tissue Eng. 2017, 8, 8. [CrossRef]

14. Cai, S.; Zhang, W.; Chen, W. PDGFR $\beta+/$ c-kit+ pulp cells are odontoblastic progenitors capable of producing dentin-like structure in vitro and in vivo. BMC Oral Health 2016, 16, 113. [CrossRef] [PubMed]

15. Gong, Y.; Yuan, S.; Sun, J.; Wang, Y.; Liu, S.; Guo, R.; Dong, W.; Li, R. R-Spondin 2 Induces Odontogenic Differentiation of Dental Pulp Stem/Progenitor Cells via Regulation of Wnt/ $\beta$-Catenin Signaling. Front. Physiol. 2020, 11, 918. [CrossRef] [PubMed]

16. Huang, G.T.-J.; Shagramanova, K.; Chan, S.W. Formation of Odontoblast-Like Cells from Cultured Human Dental Pulp Cells on Dentin In Vitro. J. Endod. 2006, 32, 1066-1073. [CrossRef]

17. Gronthos, S.; Brahim, J.; Li, W.; Fisher, L.W.; Cherman, N.; Boyde, A.; DenBesten, P.; Robey, P.G.; Shi, S. Stem Cell Properties of Human Dental Pulp Stem Cells. J. Dent. Res. 2002, 81, 531-535. [CrossRef] [PubMed]

18. Batouli, S.; Miura, M.; Brahim, J.; Tsutsui, T.; Fisher, L.; Gronthos, S.; Robey, P.; Shi, S. Comparison of Stem-cell-mediated Osteogenesis and Dentinogenesis. J. Dent. Res. 2003, 82, 976-981. [CrossRef] [PubMed]

19. Huang, G.T.-J.; Sonoyama, W.; Chen, J.; Park, S.H. In vitro characterization of human dental pulp cells: Various isolation methods and culturing environments. Cell Tissue Res. 2006, 324, 225-236. [CrossRef] [PubMed]

20. Dominici, M.; Le Blanc, K.; Mueller, I.; Slaper-Cortenbach, I.; Marini, F.; Krause, D.; Deans, R.; Keating, A.; Prockop, D.; Horwitz, E. Minimal criteria for defining multipotent mesenchymal stromal cells. The International Society for Cellular Therapy position statement. Cytotherapy 2006, 8, 315-317. [CrossRef]

21. Baldión, P.A.; Velandia-Romero, M.L.; Castellanos, J.E. Odontoblast-Like Cells Differentiated from Dental Pulp Stem Cells Retain Their Phenotype after Subcultivation. Int. J. Cell Biol. 2018, 2018, 6853189. [CrossRef]

22. Kim, Y.-H.; Cho, K.-A.; Lee, H.-J.; Park, M.; Kim, H.S.; Park, J.-W.; Woo, S.-Y.; Ryu, K.-H. Identification of WNT16 as a Predictable Biomarker for Accelerated Osteogenic Differentiation of Tonsil-Derived Mesenchymal Stem Cells In Vitro. Stem Cells Int. 2019, 2019, 8503148. [CrossRef]

23. Yan, X.; Qin, H.; Qu, C.; Tuan, R.S.; Shi, S.; Huang, G.T.-J. iPS Cells Reprogrammed From Human Mesenchymal-like Stem/Progenitor Cells of Dental Tissue Origin. Stem Cells Dev. 2010, 19, 469-480. [CrossRef] [PubMed]

24. Jeon, R.-H.; Lee, W.; Son, Y.-B.; Bharti, D.; Shivakumar, S.B.; Lee, S.-L.; Rho, G.-J. PPIA, HPRT1, and YWHAZ Genes Are Suitable for Normalization of mRNA Expression in Long-Term Expanded Human Mesenchymal Stem Cells. BioMed Res. Int. 2019, 2019, 3093545. [CrossRef] [PubMed]

25. Perez-Riverol, Y.; Csordas, A.; Bai, J.; Bernal-Llinares, M.; Hewapathirana, S.; Kundu, D.J.; Inuganti, A.; Griss, J.; Mayer, G.; Eisenacher, M.; et al. The PRIDE database and related tools and resources in 2019: Improving support for quantification data. Nucleic Acids Res. 2019, 47, D442-D450. [CrossRef]

26. Chen, H.; Boutros, P.C. VennDiagram: A package for the generation of highly-customizable Venn and Euler diagrams in R. BMC Bioinform. 2011, 12, 35. [CrossRef]

27. Hastie, T.; Tibshirani, R.; Narasimhan, B.; Chu, G. Impute: Impute: Imputation for Microarray Data. R Package Version 1.66.0. 2021. Available online: https://rdrr.io/bioc/impute/ (accessed on 17 October 2021). [CrossRef]

28. Ritchie, M.E.; Phipson, B.; Wu, D.; Hu, Y.; Law, C.W.; Shi, W.; Smyth, G.K. Limma powers differential expression analyses for RNA-sequencing and microarray studies. Nucleic Acids Res. 2015, 43, e47. [CrossRef] [PubMed]

29. Rohart, F.; Gautier, B.; Singh, A.; Le Cao, K.-A. mixOmics: An R package for 'omics feature selection and multiple data integration. PLoS Comput. Biol. 2017, 13, e1005752. [CrossRef]

30. Wickham, H. ggplot2. Wiley Interdiscip. Rev. Comput. Stat. 2011, 3, 180-185. [CrossRef]

31. Blighe, K.; Rana, S.; Lewis, M. EnhancedVolcano: Publication-Ready Volcano Plots with Enhanced Colouring and Labeling. 2021. Available online: https:/ / github.com/kevinblighe/EnhancedVolcano (accessed on 17 October 2021). 
32. Jiao, X.; Sherman, B.T.; Huang, D.W.; Stephens, R.M.; Baseler, M.W.; Lane, H.C.; Lempicki, R.A. DAVID-WS: A stateful web service to facilitate gene/protein list analysis. Bioinform. 2012, 28, 1805-1806. [CrossRef]

33. Szklarczyk, D.; Gable, A.L.; Nastou, K.C.; Lyon, D.; Kirsch, R.; Pyysalo, S.; Doncheva, N.T.; Legeay, M.; Fang, T.; Bork, P.; et al. The STRING database in 2021: Customizable protein-protein networks, and functional characterization of user-uploaded gene/measurement sets. Nucleic Acids Res. 2021, 49, D605-D612. [CrossRef]

34. Lobov, A.; Semenova, D.; Kostina, A.; Kiselev, A.; Zabirnyk, A.; Vaage, J.; Malashicheva, A. Proteo-transcriptomic analysis of osteogenic differentiation of valve interstitial cells from patients with calcific aortic valve disease. Bone Rep. 2020, 13, 100303. [CrossRef]

35. Korkmaz, Y.; Imhof, T.; Kämmerer, P.W.; Bloch, W.; Rink-Notzon, S.; Möst, T.; Weber, M.; Kesting, M.; Galler, K.M.; Deschner, J. The colocalizations of pulp neural stem cells markers with dentin matrix protein-1, dentin sialoprotein and dentin phosphoprotein in human denticle (pulp stone) lining cells. Ann. Anat.-Anat. Anz. 2022, 239, 151815. [CrossRef] [PubMed]

36. Wang, D.-R.; Wang, Y.-H.; Pan, J.; Tian, W.-D. Neurotrophic effects of dental pulp stem cells in repair of peripheral nerve after crush injury. World J. Stem Cells 2020, 12, 1196-1213. [CrossRef] [PubMed]

37. Bernal, A.; Arranz, L. Nestin-expressing progenitor cells: Function, identity and therapeutic implications. Cell. Mol. Life Sci. 2018, 75, 2177-2195. [CrossRef] [PubMed]

38. Hambiliki, F.; Ström, S.; Zhang, P.; Stavreus-Evers, A. Co-localization of NANOG and OCT4 in human prx10-implantation embryos and in human embryonic stem cells. J. Assist. Reprod. Genet. 2012, 29, 1021-1028. [CrossRef]

39. Cherepanova, O.A.; Gomez, D.; Shankman, L.S.; Swiatlowska, P.; Williams, J.; Sarmento, O.F.; Alencar, G.F.; Hess, D.L.; Bevard, M.H.; Greene, E.S.; et al. Activation of the pluripotency factor OCT4 in smooth muscle cells is atheroprotective. Nat. Med. 2016, 22, 657-665. [CrossRef] [PubMed]

40. Pallante, B.A.; Duignan, I.; Okin, D.; Chin, A.; Bressan, M.C.; Mikawa, T.; Edelberg, J.M. Bone Marrow Oct3/4+Cells Differentiate into Cardiac Myocytes via Agx10-Dependent Paracrine Mechanisms. Circ. Res. 2007, 100, 1-11. [CrossRef] [PubMed]

41. Van Schaijik, B.; Davis, P.F.; Wickremesekera, A.C.; Tan, S.T.; Itinteang, T. Subcellular localisation of the stem cell markers OCT4, SOX2, NANOG, KLF4 and c-MYC in cancer: A review. J. Clin. Pathol. 2017, 71, 88-91. [CrossRef] [PubMed]

42. Alexander, R.E.; Cheng, L.; Grignon, D.J.; Idrees, M.T. Cytoplasmic OCT4 staining is a sensitive marker of neuroendocrine differentiation. Hum. Pathol. 2014, 45, 27-32. [CrossRef] [PubMed]

43. Henderson, J.K.; Draper, J.S.; Baillie, H.S.; Fishel, S.; Thomson, J.A.; Moore, H.; Andrews, P.W. Preimplantation Human Embryos and Embryonic Stem Cells Show Comparable Expression of Stagx10-Specific Embryonic Antigens. STEM CELLS 2002, 20, 329-337. [CrossRef] [PubMed]

44. Trusler, O.; Huang, Z.; Goodwin, J.; Laslett, A.L. Cell surface markers for the identification and study of human naive pluripotent stem cells. Stem Cell Res. 2018, 26, 36-43. [CrossRef]

45. Abujarour, R.; Valamehr, B.; Robinson, M.; Rezner, B.; Vranceanu, F.; Flynn, P. Optimized Surface Markers for the Prospective Isolation of High-Quality hiPSCs using Flow Cytometry Selection. Sci. Rep. 2013, 3, 1179. [CrossRef] [PubMed]

46. Fong, C.Y.; Peh, G.; Gauthaman, K.; Bongso, A. Separation of SSEA-4 and TRA-1-60 Labelled Undifferentiated Human Embryonic Stem Cells from A Heterogeneous Cell Population Using Magnetic-Activated Cell Sorting (MACS) and Fluorescencx10-Activated Cell Sorting (FACS). Stem Cell Rev. Rep. 2009, 5, 72-80. [CrossRef]

47. Wojakowski, W.; Tendera, M.; Kucia, M.; Zuba-Surma, E.; Paczkowska, E.; Ciosek, J.; Hałasa, M.; Król, M.; Kazmierski, M.; Buszman, P.; et al. Mobilization of Bone Marrow-Derived Oct-4+ SSEA-4+ Very Small Embryonic-Like Stem Cells in Patients With Acute Myocardial Infarction. J. Am. Coll. Cardiol. 2009, 53, 1-9. [CrossRef]

48. Ramathal, C.; Reijo, R.; Turek, P. Embryonic Stem Cells and the Germ Cell Lineage. In Embryonic Stem Cells-Basic Biology to Bioengineering; InTech: London, UK, 2011. [CrossRef]

49. Mori, G.; Brunetti, G.; Oranger, A.; Carbone, C.; Ballini, A.; Muzio, L.L.; Colucci, S.; Mori, C.; Grassi, F.R.; Grano, M. Dental pulp stem cells: Osteogenic differentiation and gene expression. Ann. N. Y. Acad. Sci. 2011, 1237, 47-52. [CrossRef] [PubMed]

50. Enukashvily, N.; Dombrovskaya, J.; Kotova, A.; Semenova, N.; Karabak, I.; Banashkov, R.; Baram, D.; Paderina, T.; Bilyk, S.; Grimm, W.-D.; et al. Fibrin Glue Implants Seeded with Dental Pulp and Periodontal Ligament Stem Cells for the Repair of Periodontal Bone Defects: A Preclinical Study. Bioengineering 2021, 8, 75. [CrossRef]

51. Alipour, M.; Firouzi, N.; Aghazadeh, Z.; Samiei, M.; Montazersaheb, S.; Khoshfetrat, A.B.; Aghazadeh, M. The osteogenic differentiation of human dental pulp stem cells in alginatx10-gelatin/Nano-hydroxyapatite microcapsules. BMC Biotechnol. 2021, 21, 6. [CrossRef] [PubMed]

52. Almushayt, A.; Narayanan, K.; E Zaki, A.; George, A. Dentin matrix protein 1 induces cytodifferentiation of dental pulp stem cells into odontoblasts. Gene Ther. 2005, 13, 611-620. [CrossRef]

53. Wahab, R.M.A.; Ariffin, S.H.Z.; Yeen, W.W.; Ahmad, N.A.; Senafi, S. Molecular Markers of Dental Pulp Tissue during Orthodontic Tooth Movement: A Pilot Study. Sci. World J. 2012, 2012, 236427. [CrossRef] [PubMed]

54. Gomathi, K.; Akshaya, N.; Srinaath, N.; Moorthi, A.; Selvamurugan, N. Regulation of Runx2 by post-translational modifications in osteoblast differentiation. Life Sci. 2020, 245, 117389. [CrossRef] [PubMed]

55. Liu, J.; Yu, F.; Sun, Y.; Jiang, B.; Zhang, W.; Yang, J.; Xu, G.-T.; Liang, A.; Liu, S. Concise Reviews: Characteristics and Potential Applications of Human Dental Tissux10-Derived Mesenchymal Stem Cells. Stem Cells 2015, 33, 627-638. [CrossRef] [PubMed]

56. Bae, S.; Kang, B.; Lee, H.; Luu, H.; Mullins, E.; Kingsley, K. Characterization of Dental Pulp Stem Cell Responses to Functional Biomaterials Including Mineralized Trioxide Aggregates. J. Funct. Biomater. 2021, 12, 15. [CrossRef] [PubMed] 
57. Pisciotta, A.; Carnevale, G.; Meloni, S.; Riccio, M.; De Biasi, S.; Gibellini, L.; Ferrari, A.; Bruzzesi, G.; De Pol, A. Human Dental pulp stem cells (hDPSCs): Isolation, enrichment and comparative differentiation of two sub-populations. BMC Dev. Biol. 2015, 15, 14. [CrossRef] [PubMed]

58. Ivanovic, Z. Hypoxia or in situ normoxia: The stem cell paradigm. J. Cell. Physiol. 2009, 219, 271-275. [CrossRef] [PubMed]

59. Buravkova, L.B.; Andreeva, E.R.; Gogvadze, V.; Zhivotovsky, B. Mesenchymal stem cells and hypoxia: Where are we? Mitochondrion 2014, 19, 105-112. [CrossRef] [PubMed]

60. Ahmed, N.E.-M.B.; Murakami, M.; Kaneko, S.; Nakashima, M. The effects of hypoxia on the stemness properties of human dental pulp stem cells (DPSCs). Sci. Rep. 2016, 6, 35476. [CrossRef] [PubMed]

61. Werle, S.B.; Chagastelles, P.; Pranke, P.; Casagrande, L. The effects of hypoxia on in vitro culture of dental-derived stem cells. Arch. Oral Biol. 2016, 68, 13-20. [CrossRef] [PubMed]

62. Zayed, M.; Iohara, K.; Watanabe, H.; Ishikawa, M.; Tominaga, M.; Nakashima, M. Characterization of stable hypoxiapreconditioned dental pulp stem cells compared with mobilized dental pulp stem cells for application for pulp regenerative therapy. Stem Cell Res. Ther. 2021, 12, 302. [CrossRef] [PubMed]

63. Gagari, E.; Rand, M.K.; Tayari, L.; Vastardis, H.; Sharma, P.; Hauschka, P.V.; Damoulis, P.D. Expression of stem cell factor and its receptor, c-kit, in human oral mesenchymal cells. Eur. J. Oral Sci. 2006, 114, 409-415. [CrossRef] [PubMed]

64. Martens, W.; Wolfs, E.; Struys, T.; Politis, C.; Bronckaers, A.; Lambrichts, I. Expression Pattern of Basal Markers in Human Dental Pulp Stem Cells and Tissue. Cells Tissues Organs 2012, 196, 490-500. [CrossRef] [PubMed]

65. Cucco, C.; Zhang, Z.; Botero, T.M.; Chiego, D.J.; Castilho, R.M.; Nör, J.E. SCF/C-Kit Signaling Induces Self-Renewal of Dental Pulp Stem Cells. J. Endod. 2020, 46, S56-S62. [CrossRef]

66. Suphanantachat, S.; Iwata, T.; Ishihara, J.; Yamato, M.; Okano, T.; Izumi, Y. A role for c-Kit in the maintenance of undifferentiated human mesenchymal stromal cells. Biomaterials 2014, 35, 3618-3626. [CrossRef] [PubMed]

67. Ishkitiev, N.; Yaegaki, K.; Kozhuharova, A.; Tanaka, T.; Okada, M.; Mitev, V.; Fukuda, M.; Imai, T. Pancreatic dif-ferentiation of human dentStrober, W. 2001. 'Trypan Blue Exclusion Test of Cell Viability'. Current Protocols in Immunology/Edited by John E. Coligan. [et Al.] Appendix 3:Appendix 3B.acl pulp CD117+ stem cells. Regen. Med. 2013, 8, 597-612. [CrossRef]

68. Rabban, J.T.; Soslow, R.A.; Zaloudek, C.Z. Immunohistology of the Female Genital Tract, 3rd ed.; Elsevier Inc.: Amsterdam, The Netherlands, 2010; ISBN 9781416057666.

69. Gibson, P.C.; Cooper, K. CD117 (KIT): A Diverse Protein With Selective Applications in Surgical Pathology. Adv. Anat. Pathol. 2002, 9, 65-69. [CrossRef]

70. AlAnsary, M.; Drummond, B.; Coates, D. Immunocytochemical characterization of primary teeth pulp stem cells from three stages of resorption in serum-free medium. Dent. Traumatol. 2021, 37, 90-102. [CrossRef]

71. Yamamoto, A.; Sakai, K.; Matsubara, K.; Kano, F.; Ueda, M. Multifaceted neuro-regenerative activities of human dental pulp stem cells for functional recovery after spinal cord injury. Neurosci. Res. 2014, 78, 16-20. [CrossRef]

72. Palmer, R.; Lumsden, A. Development of periodontal ligament and alveolar bone in homografted recombinations of enamel organs and papillary, pulpal and follicular mesenchyme in the mouse. Arch. Oral Biol. 1987, 32, 281-289. [CrossRef]

73. Kehler, J.; Tolkunova, E.; Koschorz, B.; Pesce, M.; Gentile, L.; Boiani, M.; Lomelí, H.; Nagy, A.; McLaughlin, K.J.; Schöler, H.; et al. Oct4 is required for primordial germ cell survival. EMBO Rep. 2004, 5, 1078-1083. [CrossRef]

74. Yamaguchi, S.; Yamazaki, Y.; Ishikawa, Y.; Kawaguchi, N.; Mukai, H.; Nakamura, T. EWSR1 is fused toPOU5F1 in a bone tumor with translocation t(6;22)(p21;q12). Genes Chromosom. Cancer 2005, 43, 217-222. [CrossRef] [PubMed]

75. Shimazaki, T.; Okazawa, H.; Fujii, H.; Ikeda, M.; Tamai, K.; McKay, R.; Muramatsu, M.; Hamada, H. Hybrid cell extinction and rx10-expression of Oct-3 function correlates with differentiation potential. EMBO J. 1993, 12, 4489-4498. [CrossRef] [PubMed]

76. Liu, T.M.; Wu, Y.N.; Guo, X.M.; Hui, J.H.P.; Lee, E.H.; Lim, B. Effects of Ectopic Nanog and Oct4 Overexpression on Mesenchymal Stem Cells. Stem Cells Dev. 2009, 18, 1013-1022. [CrossRef] [PubMed]

77. Lengner, C.; Camargo, F.D.; Hochedlinger, K.; Welstead, G.G.; Zaidi, S.; Gokhale, S.; Schöler, H.; Tomilin, A.; Jaenisch, R. Oct4 Expression Is Not Required for Mouse Somatic Stem Cell Self-Renewal. Cell Stem Cell 2007, 1, 403-415. [CrossRef] [PubMed]

78. Takeda, J.; Seino, S.; Bell, G.I. Human Oct3 gene family: cDNA sequences, alternative splicing, gene organization, chromosomal location, and expression at low levels in adult tissues. Nucleic Acids Res. 1992, 20, 4613-4620. [CrossRef]

79. Atlasi, Y.; Mowla, S.J.; Ziaee, S.A.; Gokhale, P.J.; Andrews, P.W. OCT4 Spliced Variants Are Differentially Expressed in Human Pluripotent and Nonpluripotent Cells. Stem Cells 2008, 26, 3068-3074. [CrossRef]

80. Wang, X.; Zhao, Y.; Xiao, Z.; Chen, B.; Wei, Z.; Wang, B.; Zhang, J.; Han, J.; Gao, Y.; Li, L.; et al. Alternative Translation ofOCT4by an Internal Ribosome Entry Site and its Novel Function in Stress Response. Stem Cells 2009, 27, 1265-1275. [CrossRef]

81. Huang, C.-E.; Hu, F.-W.; Yu, C.-H.; Tsai, L.-L.; Lee, T.-H.; Chou, M.-Y.; Yu, C.-C. Concurrent Expression of Oct4 and Nanog Maintains Mesenchymal Stem-Like Property of Human Dental Pulp Cells. Int. J. Mol. Sci. 2014, 15, 18623-18639. [CrossRef]

82. Silvério, K.G.; Rodrigues, T.L.; Coletta, R.D.; Benevides, L.; Da Silva, J.S.; Casati, M.Z.; Sallum, E.A.; Nociti, F.H. Mesenchymal Stem Cell Properties of Periodontal Ligament Cells From Deciduous and Permanent Teeth. J. Periodontol. 2010, 81, 1207-1215. [CrossRef]

83. Trubiani, O.; Pizzicannella, J.; Caputi, S.; Marchisio, M.; Mazzon, E.; Paganelli, R.; Paganelli, A.; Diomede, F. Periodontal Ligament Stem Cells: Current Knowledge and Future Perspectives. Stem Cells Dev. 2019, 28, 995-1003. [CrossRef]

84. Gang, E.J.; Bosnakovski, D.; Figueiredo, C.A.; Visser, J.W.; Perlingeiro, R.C.R. SSEA-4 identifies mesenchymal stem cells from bone marrow. Blood 2007, 109, 1743-1751. [CrossRef] 
85. Semenova, D.S.; Kostina, A.S.; Mustaeva, A.M.; Klauzen, P.E.; Dobrynin, M.A.; Boyarskaya, N.V.; Dombrovskaya, Y.A.; Malashicheva, A.B.; Enukashvily, N.I. Notch-dependent activation of periodontal cells osteogenic potential. Transl. Med. 2020, 7, 21-32. [CrossRef]

86. Zhang, C.; Chang, J.; Sonoyama, W.; Shi, S.; Wang, C.-Y. Inhibition of Human Dental Pulp Stem Cell Differentiation by Notch Signaling. J. Dent. Res. 2008, 87, 250-255. [CrossRef] [PubMed]

87. Ohta, S.; Yamada, S.; Matuzaka, K.; Inoue, T. The behavior of stem cells and progenitor cells in the periodontal ligament during wound healing as observed using immunohistochemical methods. J. Periodontal Res. 2008, 43, 595-603. [CrossRef]

88. Wang, P.-W.; Wu, T.-H.; Lin, T.-Y.; Chen, M.-H.; Yeh, C.-T.; Pan, T.-L. Characterization of the Roles of Vimentin in Regulating the Proliferation and Migration of HSCs during Hepatic Fibrogenesis. Cells 2019, 8, 1184. [CrossRef] [PubMed]

89. Cheng, F.; Shen, Y.; Mohanasundaram, P.; Lindström, M.; Ivaska, J.; Ny, T.; Eriksson, J.E. Vimentin coordinates fibroblast proliferation and keratinocyte differentiation in wound healing via TGF- $\beta$-Slug signaling. Proc. Natl. Acad. Sci. USA 2016, 113, E4320-E4327. [CrossRef]

90. Xie, W.; Burke, B. Lamins. Curr. Biol. 2016, 26, R348-R350. [CrossRef]

91. Alcorta-Sevillano, N.; Macías, I.; Rodríguez, C.I.; Infante, A. Crucial Role of Lamin A/C in the Migration and Differentiation of MSCs in Bone. Cells 2020, 9, 1330. [CrossRef]

92. Felthaus, O.; Gosau, M.; Klein, S.; Prantl, L.; Reichert, T.E.; Schmalz, G.; Morsczeck, C. Dexamethasonx10-related osteogenic differentiation of dental follicle cells depends on ZBTB16 but not Runx2. Cell Tissue Res. 2014, 357, 695-705. [CrossRef]

93. Wang, Z.-Q.; Keita, M.; Bachvarova, M.; Gobeil, S.; Morin, C.; Plante, M.; Gregoire, J.; Renaud, M.-C.; Sebastianelli, A.; Trinh, X.B.; et al. Inhibition of RUNX2 Transcriptional Activity Blocks the Proliferation, Migration and Invasion of Epithelial Ovarian Carcinoma Cells. PLoS ONE 2013, 8, e74384. [CrossRef]

94. Deiana, M.; Carbonare, L.D.; Serena, M.; Cheri, S.; Parolini, F.; Gandini, A.; Marchetto, G.; Innamorati, G.; Manfredi, M.; Marengo, E.; et al. New Insights into the Runt Domain of RUNX2 in Melanoma Cell Proliferation and Migration. Cells 2018, 7, 220. [CrossRef]

95. Pratap, J.; Galindo, M.; Zaidi, K.; Vradii, D.; Bhat, B.M.; A Robinson, J.; Choi, J.-Y.; Komori, T.; Stein, J.L.; Lian, J.B.; et al. Cell growth regulatory role of Runx2 during proliferative expansion of preosteoblasts. Cancer Res. 2003, 63, 5357-5362. [PubMed]

96. Li, S.; Kong, H.; Yao, N.; Yu, Q.; Wang, P.; Lin, Y.; Wang, J.; Kuang, R.; Zhao, X.; Xu, J.; et al. The role of runt-related transcription factor 2 (Runx2) in the late stage of odontoblast differentiation and dentin formation. Biochem. Biophys. Res. Commun. 2011, 410, 698-704. [CrossRef]

97. Komori, T. Regulation of Osteoblast and Odontoblast Differentiation by RUNX2. J. Oral Biosci. 2010, 52, 22-25. [CrossRef]

98. Chen, S.; Gluhak-Heinrich, J.; Wang, Y.; Wu, Y.; Chuang, H.H.; Chen, L.; Yuan, G.; Dong, J.; Gay, I.; MacDougall, M. Runx2, Osx, andDsppin Tooth Development. J. Dent. Res. 2009, 88, 904-909. [CrossRef] [PubMed] 